\title{
Expression, Characterization, and Genomic Structure of Carp JAK1 Kinase Gene
}

\author{
MAU-SUN CHANG,${ }^{1}$ GEEN-DONG CHANG, ${ }^{2}$ JIANN-HORNG LEU, ${ }^{3}$ FORE-LIEN HUANG, ${ }^{1,3}$ \\ CHEN-KUNG CHOU, ${ }^{4}$ CHANG-JEN HUANG, ${ }^{3}$ and TUNG-BIN LO ${ }^{2,3}$
}

\begin{abstract}
A 3.7-kb cDNA encodes the carp JAK1 kinase of 1,156 amino acid residues. The overall amino acid sequence identity between carp JAK1 and murine JAK1, JAK2, JAK3, and human TYK2 is $57 \%, 35.5 \%$, 31.3\%, and 42.4\%, respectively. In addition, carp JAK1 shows higher sequence homology to mammalian JAK1 in both the kinase-like (JH2) and kinase (JH1) domains (approximately $70 \%$ identity). Therefore, carp JAK1 is a homolog of mammalian JAK1. To investigate the possible function of JH2 domain, full-length, and various truncated forms of carp JAK1 were produced in the baculovirus system. Our results demonstrate that c-JH1 and c-JH2 associate with each other and c-JH2 can be tyrosine-phosphorylated by c-JAK1 and by c-JH( $1+2)$. The JAK1 gene was also isolated from a carp genomic library and characterized. This gene is divided into 24 exons spanning at least $31 \mathrm{~kb}$ of genomic DNA. Exon 1 contains the $5^{\prime}$-untranslated region and exon 2 contains the putative translation initiation site. The 2.5 -kb DNA region upstream of the transcription initiation site contains numerous potential binding sites for transcription factors including NF-IL6, HNF-5, AP1, GHF5, and E2A. When this DNA fragment was placed upstream of the chloramphenicol acetyltransferase (CAT) reporter gene and transfected into a carp CF cell line, it could drive the synthesis of CAT enzyme 16 times more efficiently than the promoterless pCAT-Basic. Deletion analysis defined a positive regulatory region between $-1,023$ and -528 . A smaller region $(-181$ to +59$)$ without any typical TATA-box sequences, $G+C$ rich sequences, or other binding sequences for known transcription factors still had promoter activity. Constructs without this region did not have detectable promoter activity. This suggests that this region of DNA may play an important role in the expression of carp JAK1 gene.
\end{abstract}

\section{INTRODUCTION}

$\mathbf{T}$ YROSINE PHOSPHORYLATION catalyzed by protein tyrosine kinases (PTKs) is a key step in transducing signals from external stimuli to the nucleus. Therefore, PTKs play very important roles in the regulation of cell proliferation and differentiation (Hunter and Cooper, 1985; Hanks et al., 1988). On the basis of their structural similarities, PTKs can be divided into two major groups: receptor and nonreceptor PTKs. Receptor PTKs contain extracellular, transmembrane, and cytoplasmic domains. The extracellular domains are able to associate with ligands, where the cytoplasmic catalytic domains are responsible for transmission of the external signals to the cell. Upon binding of the ligand, the kinase activity of the receptor PTK is induced, resulting in phosphorylation of the receptor and cellular substrates on tyrosine residues (Ullrich and Schlessinger, 1990). By contrast, the nonreceptor PTKs, due to the lack of extracellular domains, cannot directly interact with extracellular ligands. Therefore, the physiological functions of these nonreceptor PTKs remained obscure for quite some time until the observation that $\mathrm{p} 56^{\text {lck }}$ was associated with the CD4 and CD8 co-receptors (Veillette et al., 1988). This suggests that by binding nonreceptor PTKs, some transmembrane receptors lacking TK domains can act in a manner analogous to the receptor PTKs.

\footnotetext{
${ }^{1}$ Department of Zoology, and ${ }^{2}$ Graduate Institute of Biochemical Sciences, National Taiwan University, Taipei, Taiwan.

${ }^{3}$ Institute of Biological Chemistry, Academia Sinica, Taipei, Taiwan.

${ }^{4}$ Department of Medical Research, Veterans General Hospital, Taipei, Taiwan.
} 
The polymerase chain reaction (PCR) (Mullis and Faloona, 1987) has been employed to clone potential PTKs, using degenerate oligonucleotide primers corresponding to conserved peptide fragments in kinase domains. The JAK (Janus kinase) family was first identified by this strategy (Wilks, 1989; Wilks et al., 1991). This family belongs to the nonreceptor PTKs and currently consists of JAK1 (Wilks et al., 1991; Yang et al., 1993), JAK2 (Harpur et al., 1992), JAK3 (Witthuhn et al., 1994), and TYK2 (Firmbach-Kraft et al., 1990) in mammals. These kinases lack the Src homology domains SH2 and SH3 (Pawson and Schlessinger, 1993) but bear an unusual feature of having a kinase-like domain. The functional role of TYK2 was first demonstrated by its participation in interferon (IFN) signal transduction pathway and its association with the IFN- $\alpha$ receptor (Velazquez et al., 1992). Recently, many cytokine receptors have been found to associate with one or two or more members of the JAK family, including the receptors for erythropoietin (EPO) (Witthuhn et al., 1993), growth hormone (Argetsinger et al., 1993), prolactin (Campbell et al., 1994; Da Silva et al., 1994; Rui et al., 1994), interleukin 2 (IL-2) (Miyazaki et al., 1994; Russell et al., 1994; Witthuhn et al., 1994), IL-3 (Silvennoinen et al., 1993), IL-4 (Witthuhn et al., 1994), IL-6 (Stahl et al., 1994), IL-12 (Bacon et al., 1995), oncostatin M, leukemia inhibitory factor (LIF) (Stahl et al., 1994), granulocyte-macrophage colony-stimulating factor (GM-CSF) (Quelle et al., 1994), granulocyte colony-stimulating factor (GCSF) (Nicholson et al., 1994), and IFN- $\gamma$ (Muller et al., 1993; Watling et al., 1993). Although lacking protein kinase domains, the above members of the cytokine receptor superfamily can couple ligand binding with the tyrosine phosphorylation of downstream effectors, which is mediated by association with the JAKs. The activated JAKs then phosphorylate cytoplasmic transcription factors STATs or the signal transducer and activators of transcription. After tyrosine phosphorylation, these transcription factors are homo- or heterodimerized, translocated into the nucleus, and induce transcriptional responses (Shuai $e t$ al., 1993; Darnell et al., 1994; Ihle et al., 1994; Schindler and Darnell, 1995).

In fish, growth hormone and prolactin from many species have been isolated and cloned (Chang et al., 1992a,b; Bernardi et al., 1993), whereas only one IFN from flatfish has been purified and cloned (Tamai et al., 1993). Based on a variety of studies from mammals, the JAK family members are shown to be involved in the signal transduction of growth hormone (Argetsinger et al., 1993), prolactin (Campbell et al., 1994; DaSilva et al., 1994), and interferons (Velazquez et al., 1992). Therefore, as an initial step to understand the signal transduction in fish, we started to isolate the carp JAK kinase family by PCR. As reported in this paper, a member of the JAK family was cloned and designated carp JAK1 kinase. The carp JAK1 kinase has a higher sequence homology in both $\mathrm{JH} 1$ and $\mathrm{JH} 2$ domains (70\% identity) to human and murine JAK1 (Wilks et al., 1991; Yang et al., 1993). Because the function of the JH2 domain is unknown, we explored its activity in a baculovirus expression system, which has been used to express mammalian JAK2 kinase (Quelle et al., 1994; Duhe and Farrar, 1995). We made constructs that encode full-length JAK1 (c-JAK1), the $\mathrm{JH} 1$ and $\mathrm{JH} 2$ domains alone (c- $\mathrm{JH} 1$ and $\mathrm{c}-\mathrm{JH} 2$ ), and the $\mathrm{JH} 1$ and $\mathrm{JH} 2$ domains in combination [c- $\mathrm{JH}(1+2)]$ and expressed them in the baculovirus system. Coinfection and immunopre- cipitation experiments showed that $\mathrm{c}-\mathrm{JH} 1$ and c-JH2 could associate with each other, and that c-JH2 could be tyrosine-phosphorylated by c-JAK 1 or $\mathrm{c}-\mathrm{JH}(1+2)$. Our results may provide clues concerning the function of the $\mathrm{JH} 2$ domain.

Studies by others showed that expression of most members of the mammalian JAK kinase family such as JAK 1, JAK2, and TYK2, is ubiquitous whereas only JAK3 is mainly expressed in hematopoietic cells (Ihle and Kerr, 1995). As a first step to explore the molecular basis underlying the regulation of carp $J A K I$ gene expression, we also cloned and characterized the carp $J A K I$ gene. We have mapped the carp JAKI transcription start site and characterized its promoter. With nested deletion mutants of the 5 '-flanking region fused to the chloramphenicol acetyltransferase (CAT) reporter gene, the promoter activity was characterized by transfection into a fish cell line. To our knowledge, this is the first report to characterize the genomic structure and the promoter region of JAK kinases.

\section{MATERIALS AND METHODS}

\section{Materials}

Insect Spodoptera frugiperda (Sf9) cells were grown in Grace's medium containing $10 \%$ fetal calf serum (FCS; Life Technologies, Inc., Gaithersburg, MD). Monoclonal anti-phosphotyrosine IgG clone 4G10 was purchased from Upstate Biotechnology Inc. (Lake Placid, NY).

\section{Construction of a random-primed cDNA library}

Total RNA was isolated from carp brain by the guanidinium isothiocyanate method (Chomczynski and Sacchi, 1987), followed by the use of a QuickTrack mRNA isolation kit (Stratagene, La Jolla, CA). The isolated mRNA was used for the synthesis of random-primed cDNA.

\section{Amplification of DNA fragments by PCR}

Degenerate primers (Walks, 1989) were designed to fit the amino acid sequences that are conserved among PTKs (Hanks et al., 1988; Hanks, 1991). The amino acid sequences of the two opposing primers are HRDLAAR (subdomain VI in Fig. 2, below) and DVWSFG (subdomain IX). The first-strand carp brain cDNA was used as template. The conditions for the reaction were $94^{\circ} \mathrm{C}$ for $1 \mathrm{~min}, 45^{\circ} \mathrm{C}$ for $1 \mathrm{~min}$, and $72^{\circ} \mathrm{C}$ for 2 $\min$ in 30 cycles.

\section{cDNA library screening}

An oligo-(dT)-primed carp liver cDNA library in the lamda ZAP II (Short et al., 1988) obtained from Stratagene was screened by using a PCR-amplified DNA fragment as a probe (see Results). The probe was labeled using a DIG DNA Labeling Kit (Boehringer Mannheim, Mannheim, Germany). Hybridization and washing were carried out according to the standard procedures (Sambrook et al., 1989). Signals were detected using the DIG Luminescent Detection Kit for Nucleic Acids (Boehringer Mannheim). Putative positive plaques were purified through several rounds of rescreening at lower densities and then excised as pBluescript plasmids according to the manufacturer's instructions. To isolate the full-length cDNA, 
the 300-bp DNA fragment from the 5' end of pJ21 (Fig. 1) was amplified by PCR, DIG-labeled, and then used as a probe to screen another random-primed carp brain cDNA library as described above.

\section{Sequence analysis}

cDNA clones were subcloned into plasmid pUC18 (YanischPerron et al., 1985) and sequenced by the dideoxy chaintermination method (Sanger et al., 1977) using a Sequenase kit (United States Biochemical Corp. Cleveland, OH). Several programs from IntelliGenetics (Mountain View, CA) were used to analyze the nucleotide sequences.

\section{DNA constructions}

DNA fragments encoding the entire carp JAK1 were amplified with overlap extension PCR (Ho et al., 1989) from J9 and J21 cDNA (Fig. 1) by using the following primers: primer F1, 5'-ATATCAGGATCCATGCCAGAACTAGCAGTCATG$3^{\prime}$ and primer R1, 5'-GTGGAAACTCAGCTGGCTGAC-3'; primer F2, 5'-GTCAGCCAGCTGAGTTTCCAC-3' and primer R2, 5' -CAGTACAAGCTTCTCATCTTATTTCCATAGTTA$3^{\prime}$. The nucleotide sequences of primers $\mathrm{R} 1$ and $\mathrm{F} 2$ are complementary and they are located at the end of clone J9. Other DNA fragments encoding the kinase-like domain, kinase domain, and both domains were amplified with the PCR from J21 cDNA by using the following primers: c-JH2 (residues 572-875), 5'-ATATCAGGATCCCAGCTGAGTTTCCACCGCATC3' $^{\prime}(\mathrm{F} 3)$ and 5'-CAGTACAAGCTTGAGGAACCTCTTCTCAAACAC-3'(R3); c-JH1 (residues 869-1,156), 5'ATATCAGGATCCGTGTTTGAGAAGAGGTTCCTC-3'(F4) and 5'-CAGTACAAGCTTCTCATCTTATTTCCATAGTTA$3^{\prime}(\mathrm{R} 2)$; $\quad$ c-JH( $(1+2)$ (residues 572-1,156), 5'-ATATCAGGATCCCAGCTGAGTTTCCACCGCATC-3'(F3) and $5^{\prime}$ CAGTACAAGCTTCTCATCTTATTTCCATAGTTA-3'(R2). Each primer encodes a unique restriction site (underline) (Bam HI, GGATCC; and Hind III, AAGCTT). The PCR products

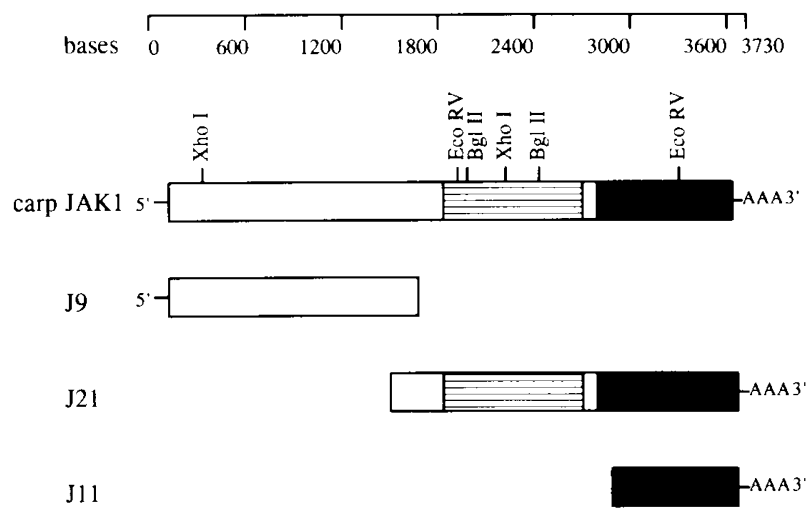

FIG. 1. Restriction maps of carp JAK1 cDNA clones. The kinase-like (JH2) and kinase ( $\mathrm{JH} 1)$ domains are represented by the horizontally striped and black boxes, respectively. Restriction enzyme sites are shown above carp JAK1 cDNA. The poly(A) tail is represented by AAA. The cDNA clones, J11 and $\mathrm{J} 21$, were isolated from a carp liver library whereas the clone $\mathrm{J} 9$ was isolated from a carp brain library. were then restricted with Bam $\mathrm{HI}$ and Hind III and ligated into pQE30 (QIAGEN Inc., Chatsworth, CA). DNA sequence analysis was performed to confirm the accuracy of the PCR products.

\section{Expression in Escherichia coli}

All the resulting plasmids (pQEJAK1, pQEJH(1 +2 ), pQEJH1, and pQEJH2) were transformed into $E$. coli strain JM109. The transformants were grown overnight at $37^{\circ} \mathrm{C}$ in $\mathrm{LB}$ broth and diluted 1:10 into fresh medium. After incubation at $37^{\circ} \mathrm{C}$ for $1 \mathrm{hr}$, isopropyl- $\beta$-D-thiogalactopyranoside (IPTG) was added to a final concentration of $1 \mathrm{mM}$, and incubation was continued for $3 \mathrm{hr}$. Cells were collected by centrifugation. Due to all the recombinant proteins contain a stretch of six histidines, therefore these proteins can be purified by using $\mathrm{Ni}^{2+}$-nitrilotriacetate-agarose (Ni-agarose) (QIAGEN Inc.) according to the procedures as described (Huang et al., 1995).

\section{Antibodies}

Purified recombinant protein c-JH1 or c-JH2 was dissolved in phosphate buffer saline (PBS) and mixed thoroughly with an equal volume of Freund's complete adjuvant for the first injection of Freund's incomplete adjuvant for the second and third injection. Approximately $100 \mu \mathrm{g}$ of recombinant protein, for each injection, was subcutaneously injected into the back of guinea pig.

\section{Expression in the baculovirus system}

All of the pQE30 constructs described in the $E$. coli expression system were digested with $E c o$ RI and $X b a$ I and then ligated into the transfer vector PVL1393 (PharMingen, San Diego, CA). Plasmids (0.5 $\mu \mathrm{g}$ of each) were co-transfected into Sf9 cells with $0.1 \mu \mathrm{g}$ of "Baculogold" virus DNA (PharMingen), which contained a lethal deletion. The parental baculovirus is unable to infect insect cells and only recombinant baculovirus containing the plasmid construct can replicate in Sf9 cells.

Sf9 cells were infected with various baculovirus at a multiplicity of infection (moi) of 10 plaque-forming units/cell. After $60 \mathrm{hr}$, cells were harvested, washed, and lysed in a buffer containing $150 \mathrm{~m} M \mathrm{NaCl}, 1 \%$ Triton $\mathrm{X}-100$, and $50 \mathrm{~m} M$ Tris $\mathrm{pH}$ 7.5. The Triton-insoluble cell pellets were solubilized in a buffer containing $1.5 \% \mathrm{~N}$-lauroylsarcosine, $25 \mathrm{mM}$ triethanolamine, and $1 \mathrm{~m} M$ EDTA pH 8.0 (Frankel et al., 1991). Both Triton-soluble and -insoluble fractions were incubated with the $\mathrm{Ni}$-agarose. After extensive washing with $0.5 \mathrm{M} \mathrm{NaCl}$, proteins were eluted by $0.1 M$ EDTA pH 8.0. An equivalent amount of protein was subjected to $\mathrm{NaDodSO}_{4}$-polyacrylamide gel electrophoresis (PAGE), blotted to nitrocellulose paper, and probed with different antibodies.

\section{Western blot}

The method of Tricine $\mathrm{NaDodSO}_{4}$-PAGE (Schagger and von Jagow, 1987) was used. The gel concentration was 7.5\%. After $\mathrm{NaDodSO}_{4}$-PAGE, the proteins were analyzed by immunoblot using anti-PY mAb or polyclonal antibodies specific for $\mathrm{JH} 1$ or $\mathrm{JH} 2$ domain according to the procedures as described (Huang et al., 1995). 


\section{Immunoprecipitation}

Sf9 cells were coinfected with vAcJH2 and vAcJH1. After $60 \mathrm{hr}$, cells were collected and solubilized by resuspension and incubation in the immunoprecipitation buffer $(50 \mathrm{mM}$ Tris pH 7.4, $150 \mathrm{~m} M \mathrm{NaCl}, 1 \mathrm{mM} \mathrm{Na} \mathrm{NO}_{4}$ and $1 \% \mathrm{NP}-40$ ). Immunoprecipitation was performed by the addition of anti-JH1 or anti-JH2 antiserum at a dilution of 1:100 or with preimmune serum as a control reaction. The mixture $(200 \mu \mathrm{l})$ was incubated at $4^{\circ} \mathrm{C}$ for $2 \mathrm{hr}$ followed by an incubation with $50 \mu \mathrm{l}$ of $50 \mathrm{mg} / \mathrm{ml}$ slurry of Protein A-Sepharose (Pharmacia, Uppsala, Sweden) for $1 \mathrm{hr}$. The Sepharose was collected and washed three times with the immunoprecipitation buffer and two times with $20 \mathrm{~m} M$ Tris pH 7.4, $1 \mathrm{~m} M$ EDTA/1 m $M$ EDTA. Samples were then boiled in a $0.5 \% \mathrm{NaDodSO}_{4}$ sample buffer to disrupt the complexes. Products were subjected to $\mathrm{NaDodSO}_{4}$-PAGE and analyzed by immunoblot using anti-PY mAb or polyclonal antibodies specific for the $\mathrm{JH} 1$ or $\mathrm{JH} 2$ domain.

\section{Reverse transcription and PCR}

mRNA $(0.5 \mu \mathrm{g})$ isolated from carp brain and liver tissues was incubated at $65^{\circ} \mathrm{C}$ for $5 \mathrm{~min}$ in a buffer containing $50 \mathrm{mM}$ Tris- $\mathrm{HCl}, 75 \mathrm{mM} \mathrm{KCl}, 3 \mathrm{~m} M \mathrm{MgCl}_{2}, 10 \mathrm{~m} M$ dithiothreitol, 2 units of RNasin and $1.25 \mathrm{~m} M$ deoxynucleotide triphosphatates (dGTP, dATP, dTTP, and dCTP), and then kept on ice. Two hundred units of Superscript Moloney murine leukemia virus reverse transcriptase (RT; GIBCO BRL, Gaithersburg, MD) and oligo(dT) $)_{12-18}$ primer $(2 \mu \mathrm{g})$ and random hexamer primers $(2$ $\mu \mathrm{g}$ ) were added and incubated at $37^{\circ} \mathrm{C}$ for $1 \mathrm{hr}$. The reaction was then stopped by incubation at $95^{\circ} \mathrm{C}$ for $5 \mathrm{~min}$.

Five sets of specific primers, F1/R1, F1/R2, F3/R3, F4/R2, and F3/R2 were used and their sequences were described in the DNA Construction section. PCR was then carried out by addition of the heat-treated RT mixture, PCR buffer, and Taq polymerase (Promega, Madison, WI). Only the amplified DNA fragments by F3/R3 and F4/R2 from brain tissues and PCR product by $F 1 / R 1$ from liver tissues were isolated from an agarose gel and subcloned into the pGEM-T vector (Promega). Other analytical methods were the same as described in the section of Sequence Analysis.

\section{Isolation of carp JAK1 genomic clones}

A commercially available carp liver lambda FIX II genomic library (Stratagene) was used to isolate 15 - to $18-\mathrm{kb}$ genomic DNA clones containing the gene that encodes carp JAK1. Fulllength carp JAK1 cDNA was labeled using a DIG DNA Labeling Kit (Boehringer Mannheim). Approximately $1 \times 10^{6}$ independent clones were plated at a density of $5 \times 10^{4}$ plaque forming units/150-mm Petri dish. Hybridization and washing were carried out as described above. Signals were detected using the DIG Luminescent Detection Kit for Nucleic Acids
(Boehringer Mannheim). Putative positive plaques were further purified through several rounds of rescreening at lower densities. Four distinct carp genomic DNA clones (designated J1, J2, $\mathrm{J} 3$, and J4) were isolated, and DNA was prepared from each clone. These carp genomic clones were digested with various restriction endonucleases. The DNA fragments were fractionated by electrophoresis in $1 \%$ agarose gels and transferred to nylon filters (Sartorius AG, Goettingen, Germany). The resulting DNA blots were probed under the above conditions of high stringency with the DIG-labeled whole carp JAKI cDNA.

\section{Sequence analysis of genomic clones that encode carp JAK1}

Phage DNA was digested with Not I, Sac I, Sal I, and Xba I and subcloned into either the pUC18 or pBluescript vector. Each subclone was sequenced by the dideoxy chain-termination method (Sanger et al., 1977) using the Sequenase protocols from United States Biochemical. The nucleotide sequences of each DNA fragment were determined using T3 and T7 primers from both ends. Additional nucleotide sequences were determined using different sets of 20-nucleotide primers synthesized based on the known sequences from both ends of each DNA fragment. The sizes of the introns were determined either by restriction enzyme mapping of genomic clones or by PCR using sense and antisense specific primers that are from two different exons. The genomic DNA sequence was analyzed with the Genetics Computer Group software program. The transcription factor recognition site data bases (releases 7.3 and 6.5) were used to identify potential transcription factor motifs within the $5^{\prime}$-flanking region of the carp $J A K 1$ gene.

\section{Primer extension analysis}

An antisense oligonucleotide ( $5^{\prime}$-GTTTAATTTCGATCATTACAGACGTTTG-3') complementary to the $5^{\prime}$ end of carp JAK 1 cDNA clone J9 (Fig. 1) was labeled at the $5^{\prime}$ end with $\left[\gamma_{-}{ }^{32} \mathrm{P}\right] \mathrm{ATP}$ by $\mathrm{T} 4$ polynucleotide kinase and purified on a Stratagene NucTrap probe purification column. The labeled primer was annealed to $5 \mu \mathrm{g}$ of poly $(\mathrm{A})^{+}$RNA prepared from adult carp liver total RNA and extendes with Moloney murine leukemia virus (M-MLV) reverse transcriptase (GIBCO BRL) as described previously (Sambrook et al., 1989). The extended products were analyzed on a $5 \%$ polyacrylamide, $7 \mathrm{M}$ urea sequencing gel. The size of the extended products was inferred from a sequencing ladder of the $J A K l$ gene obtained from the same primer used for primer extension.

\section{Plasmid construction for CAT functional analysis}

A 3-kb Sal I fragment encompassing for 5'-flanking region was subcloned into pBluescript and various deletion mutants were generated from this clone by PCR using specific primer

FIG. 2. Amino acid sequence alignment of the carp, mouse (Yang et al., 1993) and human (Wilks et al., 1991) JAK1 proteins. Alignments were initially made by computer analysis and were subsequently aligned by inspection. Gaps are introduced to optimize alignment and shown as dots. The identical residues are represented by dashes. The putative kinase domains are delineated with arrows. Subdomains Ia-XIa of the kinase-line domain and subdomains I-XI of the kinase domain are denoted according to the previous reports (Hanks et al., 1988; Hanks, 1991). The sequence of carp JAK1 has been deposited in the GenBank/EMBL Data Libraries, accession number L24895. 


\begin{tabular}{|c|c|c|}
\hline AK1 & MELGRQLCGKMKKQRKAEMTVLTVMKGLEIHFYLPDTHQLEYFKDCHTAEDL & \\
\hline mJAK1 & ILNI KEDCNAMAF-A- -RSFK - T - VKQVVPEP-V-VT--L-REP-RLGSGEY - - E- & \\
\hline hJAK1 & 2YLNI KEDCNAMAF - A - -RSSK - T - VNLEAPEP -V-VI - - S-REP - RLGSGEY - - -E- & \\
\hline AK1 & 'ALSEESQDLWYAPNHAFKITEETSIKLHYRMRFYF" & \\
\hline mJAK1 & 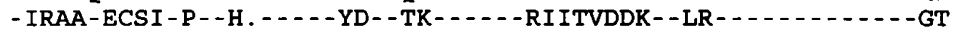 & \\
\hline hJAK1 & [RAA-ACRI - P- -H. - - - YD-NTK--1--RTITVDDKM-LR--1-1-1,-GT & 11 \\
\hline AK1 & RTESPVWRHSLFKHKGVSVSPKGPEGTPLLDAASLEYLFAQGQYDFLRGLAPVRAPQNE & \\
\hline K1 & DN-QS- - - - PK-Q-NGYEKKRV-EA- & \\
\hline hJAK1 & ON-QS - - - PK-Q-NGYEKKKI - DA- & \\
\hline JAK1 & LAITHHAKSNDLPLSGVGAETSYKRFIPI & \\
\hline & -S-- -MMKKMQ-PELPKD & \\
\hline hJAK1 & DG-D-1. & \\
\hline AK1 & NNVFKNFLNEFNSKTIQDSNITLYDLKVKYLSTLETLTQGLGRETIEPKILKVSGESDG & \\
\hline & -D- $-\mathrm{K}-\mathrm{-N}-\mathrm{C}-\mathrm{C}-\mathrm{SVSTH}-\mathrm{C}$ - & \\
\hline hJAK & 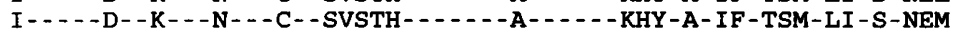 & \\
\hline AKI & SPALTLPSGDDG. LGYEVQVSGTTGISW & \\
\hline & $-\mathrm{RCHS}$ & \\
\hline hJAK1 & NWFHSNDG-NVLYYEVM-TGNLGIQWRHKPNV-SVEKEKNKLKRK-LEYNKDKKDE-KN- & \\
\hline JAKI & YRDAALSFAALVDGYFRLTVD & \\
\hline $\mathrm{mu}_{\mathbf{4}}$ & 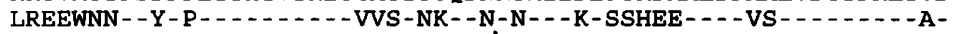 & \\
\hline hJAK & 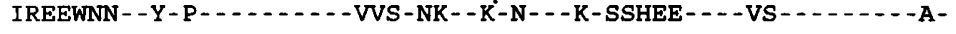 & \\
\hline I & YIIMT & \\
\hline $\mathrm{AK1}$ & 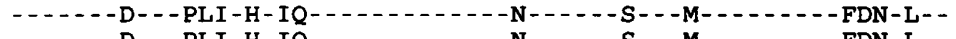 & \\
\hline AK1 & - & \\
\hline CJAK1 & VVCIEMDLCESR & \\
\hline m & $-M N--K K-I---D-I S-$ & \\
\hline hJAKI & -T-F-KSEQVQGAQK-F-..--VQKGR-S & \\
\hline & OPVLVGLGOPRK ISNLLVMTRDREPDSOROPOVSOLSFHRILKEE IVOGEHLGRGTRTNT & \\
\hline AK1 & 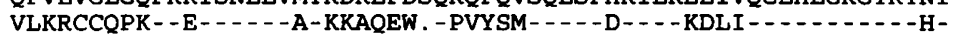 & \\
\hline hJAK & 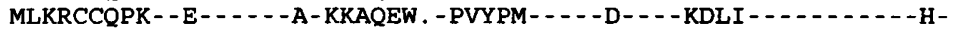 & \\
\hline & $\star \star \star$ IIIa $\star \star \star \star$ & \\
\hline AK1 & YSGVLKLKSEDDDDMGGYSQEVKVILKVLC & \\
\hline & 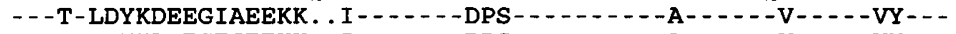 & \\
\hline hJAK1 & - - -Y-MDYKD-EGTSEEKK . . I - - - - DPS - $\ldots$ & \\
\hline & $* \star * V a * \star \star \star \star \star *$ & \\
\hline 1 & WKFQVAKQLAGALSYLEDKKLVHGNV & \\
\hline & 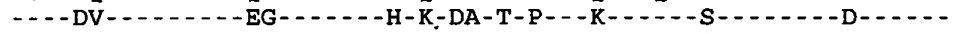 & \\
\hline TAK & $---D V-------$ EG- - - - - H-K-DV & \\
\hline & $\star \star \star \star V I I a \star \star \star \star \star$ & \\
\hline AK & CSKNILVARDGLDGEGGPFIKLSDPGIPI & \\
\hline $\mathrm{K} 1$ & $-T--L-L--E-I-S D I-\cdots$ & \\
\hline AK1 & -T- -L-L- -E-I-S-C- - - - - - - IT & \\
\hline & $\mathrm{Xa} \star \star \star \star$ & \\
\hline & EIPLKDKKLTEKERF & \\
\hline & $-\mathrm{N}--$ & 83 \\
\hline JAKI & 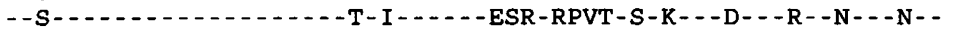 & 83 \\
\hline & KVELCRY & \\
\hline & $\ldots . .$. & 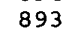 \\
\hline IJAK1 & 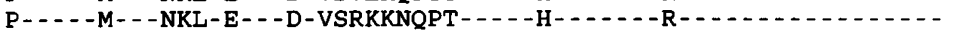 & ( \\
\hline & & \\
\hline & RGDRTGELVAVI & \\
\hline & 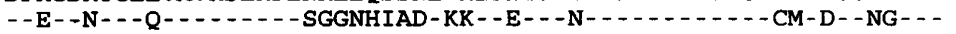 & \\
\hline IJAK1 & $--\mathrm{E}-\mathrm{-N}---\mathrm{Q}--------\mathrm{SGGI}$ & \\
\hline & *** & \\
\hline 1 & AEFLPAGSLKEYLF & \\
\hline & $-\bar{K}---Y-G--Q-V--$ & \\
\hline & 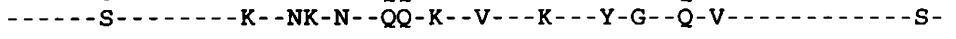 & 101 \\
\hline & & \\
\hline & APECLIH & \\
\hline & I-- & \\
\hline & 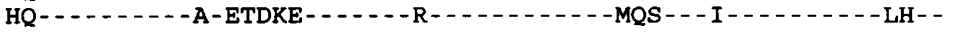 & 107 \\
\hline & & \\
\hline & YCDIS & \\
\hline & $---\mathrm{F}$ & \\
\hline hJAKI & $---\mathrm{K}---\mathrm{F}$ & 113 \\
\hline & & \\
\hline & D חע山D & \\
\hline$n \mathrm{~J}$ & EG-EALLK & \\
\hline
\end{tabular}




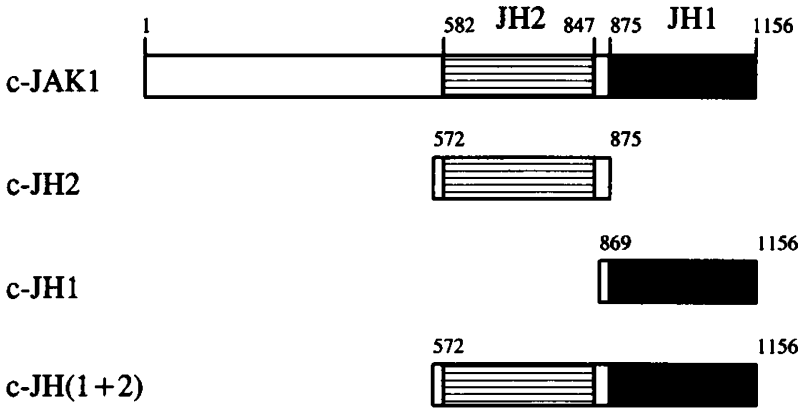

FIG. 3. Schematic diagrams of full-length and the various truncated forms of carp JAK1 constructs. The kinase-like and kinase domains are represented by horizontally striped and dark box, respectively. Truncated molecules were constructed as described in the text.

sets. PCR products were then cloned into polylinker regions of the reporter vector pCAT-Basic (Promega). Clone pJP1 contains the flanking region fragment JP1, nucleotides $-2,541$ to +59 . JP1 was synthesized using PCR primers 5' -TTGAAGCTTTCCTCCTAGGATCAGG-CAGA-3' (nucleotides $-2,541$ to $-2,522$ ) and $5^{\prime}$-GGGTCTAGATGCTTCAGTCGT-CATGATCAA-3' (nucleotides +39 to +59 ) on the 3-kb Sal I fragment. The oligonucleotide primers have additional sequences of $H$ ind $\mathrm{III}$ and $\mathrm{Xba}$ I sites at each end, respectively. Fragment JP1 was purified from the gel, digested with Hind III and Xba I, and then cloned into the same sites of pCAT-Basic. Clone spJP2, pJP3, pJP4, pJP5, and pJP6 were similarly constructed, except that the JP1 fragment was replaced with JP2 (nucleotides $-2,541$ to -181 ), JP3 (nucleotides $-2,541$ to -901 ), JP4 (nucleotides $-1,023$ to +59 ), JP5 (nucleotides -528 to +59 ), and JP6 (nucleotides -181 to +59), respectively. The pRSV-CAT (Gorman et al., 1983) was used as a positive control.

\section{Transfection, CAT, and $\beta$-galactosidase assay}

Carp fin epitheloid cells, CF (Chen and Kou, 1986), were maintained in Leibovitz's L-15 medium supplemented with $10 \%$ fetal calf serum (FCS) at $27^{\circ} \mathrm{C}$. Subconfluent cultures (approximately $60 \%$ confluent, $24 \mathrm{hr}$ after plating) in $60-\mathrm{mm}$ culture dishes were washed twice with Leibovitz's L-15 medium, and incubated with DNA-Lipofectamine complexes containing $20 \mu \mathrm{g}$ of the different CAT constructs together with $5 \mu \mathrm{g}$ of pSV- $\beta$-galactosidase ( $\beta$-GAP) vector (Promega) in duplicate. Transfection was carried out for $5 \mathrm{hr}$, and cells were washed with fresh Leibovitz's L-15 medium and fed with the same medium supplemented with $10 \%$ FCS. After $40 \mathrm{hr}$, cells were harvested, washed in phosphate-buffered saline (PBS), and lysed with $25 \mathrm{~m} M$ Tris phosphate pH 7.8, containing $2 \mathrm{mM}$ dithiothreitol, $2 \mathrm{mM}$ EDTA, $10 \%$ glycerol, and $1 \%$ Triton $\mathrm{X}$ 100 at room temperature for $30 \mathrm{~min}$. The total lysates were scraped from the dish and transferred to microcentrifuge tubes. Cell debris was removed by centrifugation and the extracts were frozen at $-70^{\circ} \mathrm{C}$ until use. Protein concentration was measured by the Bio-Rad protein concentration quick-assay method (BioRad, Richmond, CA). The pSV- $\beta$-Gal vector (Promega) carrying the SV40 promoter linked to the $\beta$-Gal gene was used to normalize the samples for differences in transfection efficiency. CAT and $\beta$-Gal activities in the extracts were measured according to the previous procedures (Herbomel et al., 1984). The acetylated products of the CAT assay were separated by thinlayer chromatography developed with chloroform-methanol (95:5, vol/vol), visualized by autoradiography and quantitated by using a PhosphoImager (Bio-Imaging Analyzer BAS 2000, Fuji, Japan).

\section{RESULTS}

\section{Isolation of carp JAKI cDNA}

We amplified carp brain cDNA by PCR using degenerate primers, an approach shown to be effective in isolating human and murine JAK1 gene (Wilks et al., 1991; Yang et al., 1993).
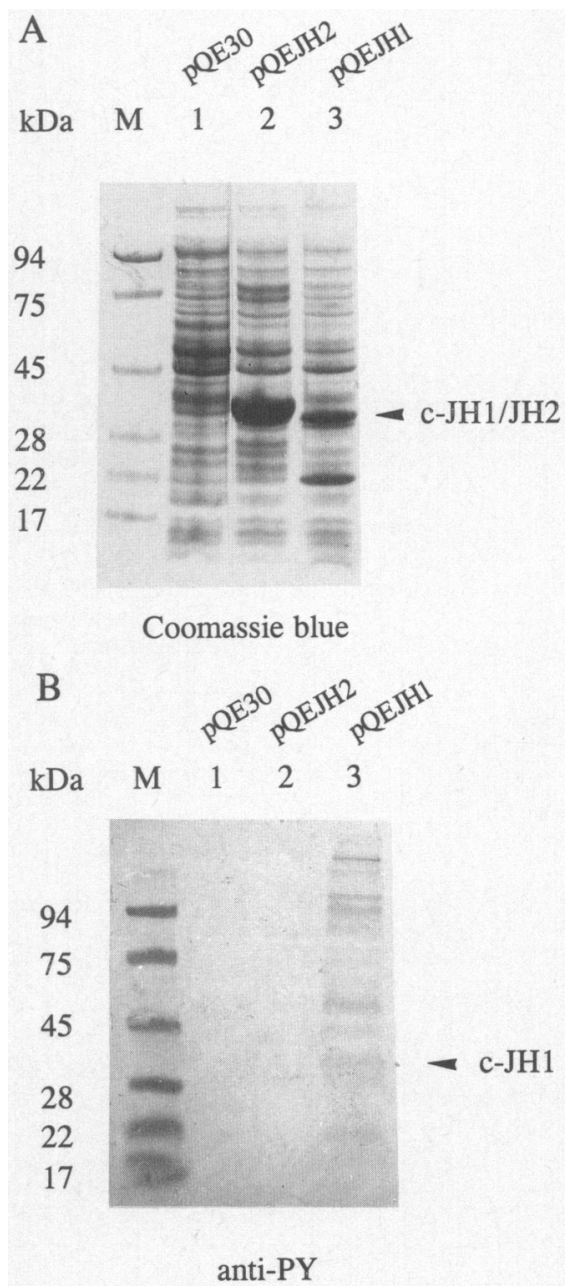

FIG. 4. Demonstration of tyrosine kinase activity of c-JH1 in E. coli. Strain JM109 cells were transformed with pQE30 (lane 1), pQEJH2 (lane 2), and pQEJH1 (lane 3), respectively. After induction with $1 \mathrm{mM}$ IPTG for $3 \mathrm{hr}$, proteins were prepared and separated by $\mathrm{NaDodSO}_{4}$-PAGE and stained with Coomassie blue (A) or immunoblotted with anti-PY mAb (B). Positions of c-JH1 and $\mathrm{c}-\mathrm{JH} 2$ are shown on the right. Lane M, Prestained molecular mass markers. 
Amplified fragments of about $220 \mathrm{bp}$ were purified and ligated into pGEM-T (Promega). Among the 20 clones sequenced, 15 clones contained a single JAK-related sequence. Using this DNA fragment as a probe, we screened an oligo(dT)-primed carp liver cDNA library. Schematics of the two representative carp liver JAK1 clones obtained from this screen are shown in Fig. 1. On the basis of DNA sequence analysis, these two clones, $\mathrm{pJ} 11$ and $\mathrm{pJ} 21$, are identical except that $\mathrm{pJ} 11$ is $0.7 \mathrm{~kb}$ whereas $\mathrm{pJ} 21$ is $2.1 \mathrm{~kb}$ in length. It was found that pJ21 encodes the carp homolog of mammalian JAK1, containing residues from 465 to 1,156 . To obtain the full-length cDNA clone, a 300-bp DNA fragment from the $5^{\prime}$ end of pJ 21 was used as a probe to screen a carp brain cDNA library. This screening yielded pJ9 $(1.9 \mathrm{~kb})$, as shown in Fig. 1. Therefore, the full-length carp JAK1 cDNA sequences are derived from the two overlapping clones, pJ9 and $\mathrm{pJ} 21$, and contain a $5^{\prime}$-untranslated region of 186 nucleotides, a coding region of 3,468 nucleotides, and a $3^{\prime}$ untranslated region of 65 nucleotides. The total length of carp JAK1 cDNA is 3,719 nucleotides. (The sequence has been deposited in GenBank with an accession number L24895.)

\section{Structure and the activity of carp JAK1 cDNA}

The complete sequence of carp JAK1 cDNA encodes an open reading frame of 1,156 amino acid residues with a predicted molecular mass of $129 \mathrm{kD}$ and the protein was termed carp JAK1. All members of the JAK family have seven homologous domains in the molecule that have been named as JHs or JAK homology domains. JH1 is a carboxy-terminal kinase-catalytic domain whereas $\mathrm{JH} 2$ is a kinase-like domain; the other five JHs are present in the far amino-terminal part. Amino acid sequence comparison of carp JAK1 with human and murine JAK1 (Wilks $e t$ al., 1991; Yang et al., 1993) is shown in Fig. 2. There is a higher sequence homology in both $\mathrm{JH} 1$ and $\mathrm{JH} 2$ (70\% identity). The overall sequence identity between carp and human/murine JAK1 is about $57 \%$. When the deduced amino acid sequences of carp JAK1 were compared with those of murine JAK2 (Harpur et al., 1992), murine JAK3 (Witthuhn et al., 1994), and human TYK2 (Firmbach-Kraft et al., 1990), it was found that the sequence homology is lower in JH1 $(50,46$, and $56 \%$ identity, respectively) and $\mathrm{JH} 2(45,43$, and $51 \%$ identity, respectively). The overall sequence identity between carp JAK1 and murine JAK2, murine JAK3, and human TYK2 is $35 \%, 31 \%$, and $42 \%$, respectively.

To test whether the $\mathrm{JH} 1$ or $\mathrm{JH} 2$ domains possess kinase-catalytic activity, we generated His-tag fusion proteins of the $\mathrm{JH} 2$ domain (c-JH2) and the JH1 domain (c-JH1) of carp JAK1 (Fig. 3 ), and expressed these fusion proteins in E. coli (Fig. 4A). The tyrosine kinase activity resulting from each fusion protein can be detected by anti-phosphotyrosine monoclonal antibodies (anti-PY $\mathrm{mAb}$ ). Due to the lack of endogenous tyrosine kinases in $E$. coli, there is little or no cross-reactive background for the anti-PY Western blot (Fig. 4B, lane 1). Among the expressed fusion proteins (Fig. 4A), only c-JH1 displayed tyrosine kinase activity and several tyrosine-phosphorylated bands including a band corresponding to $\mathrm{c}-\mathrm{JH} 1$ were detected (Fig. 4B, lane 3). By contrast, c-JH2 (lane 2) did not express any observable tyrosine kinase activity. These results are consistent with an earlier report (Wilks et al., 1991) and suggest that only JH1 is a functionally active kinase domain. c-JH1 and c-JH2 were further purified by $\mathrm{Ni}$-agarose affinity chromatography and used to generate polyclonal antibodies (see below).
Full-length and various truncated forms of carp JAKI are produced in insect cells using the baculovirus system

Figure 5, A and B, show that c-JAK1, c-JH(1 + 2), c-JH1, and $\mathrm{c}-\mathrm{JH} 2$ were present in both the Triton-soluble and Triton-
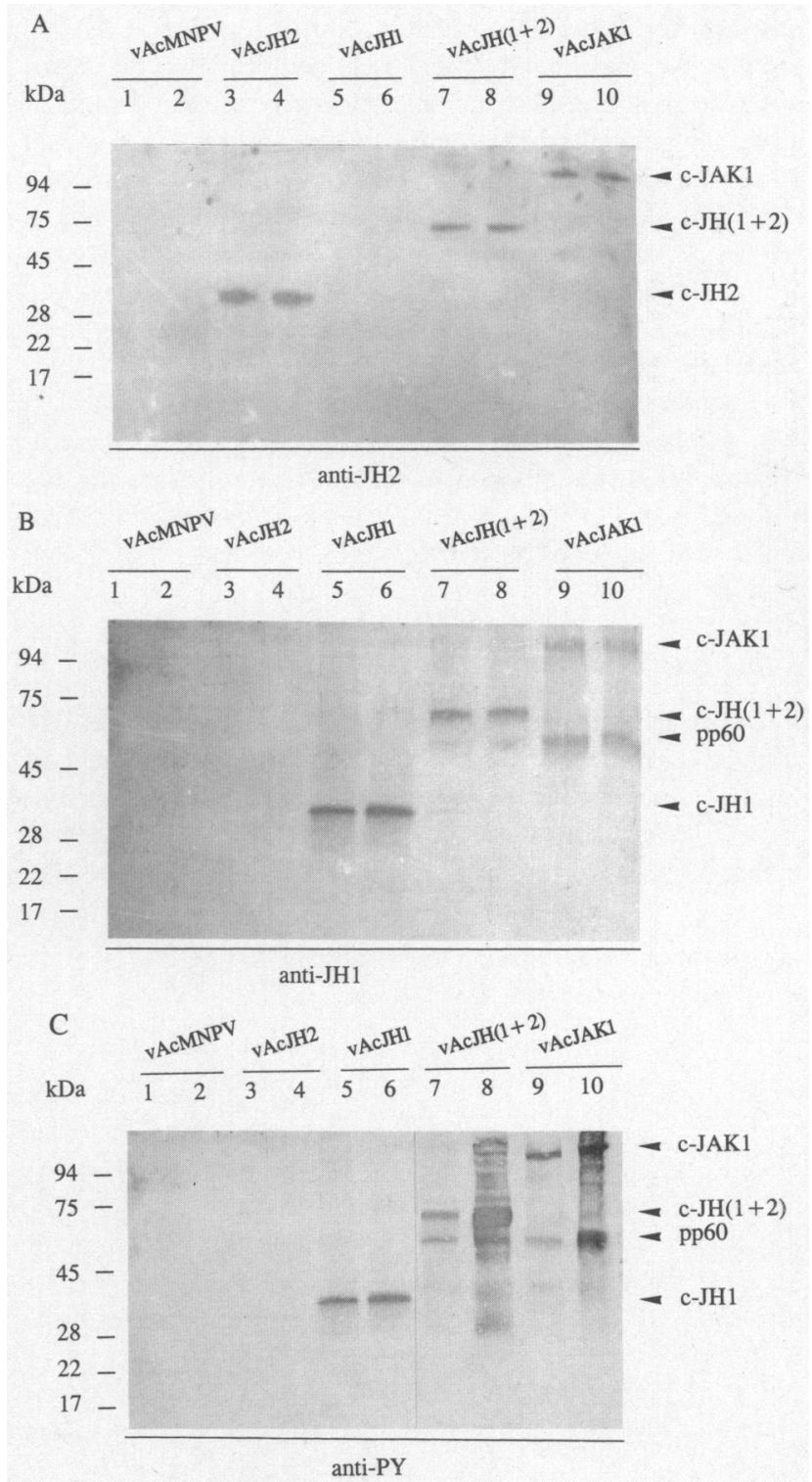

FIG. 5. Expression of full-length and various truncated forms of carp JAK 1 in the baculovirus system. Sf9 cells were infected with wild-type baculovirus, AcMNPV (lanes 1 and 2) and a variety of recombinant baculovirus (lanes 3-10), respectively. After $60 \mathrm{hr}$, cells were harvested and separated into Tritonsoluble (lanes 1, 3, 5, 7, and 9) and Triton-insoluble fractions (lanes 2, 4, 6, 8, and 10). Both fractions were further bound to $\mathrm{Ni}$-agarose gels as described in the text and equivalent amounts of bound patients were separated by $\mathrm{NaDodSO}_{4}$-PAGE, transferred to nitrocellulose, and immunoblotted with polyclonal antibodies specific for $\mathrm{JH} 2$ domain (anti-JH2; A), for $\mathrm{JH} 1$ domain (anti-JH1; B), and a mAb for phosphotyrosine (anti-PY; C). Positions of prestained molecular mass standards and their apparent sizes, in kilodaltons, are indicated on the left. 
insoluble fractions as revealed by antibodies specific for $\mathrm{JH} 2$ (Fig. 5A) and for JH1 (Fig. 5B). Again, the anti-PY mAbs were used to detect the tyrosine kinase activity of each fusion protein. As a control, Sf9 cells were infected by wild-type baculovirus and there was little or no cross-reactive background for the anti-PY Western blot (Fig. 5C, lanes 1 and 2). As shown in Fig. 5C (lanes 3 and 4), c-JH2 did not display tyrosine kinase activity. Other fusion proteins, c-JAK1, c-JH( $1+2)$, and c-JH1 all expressed tyrosine kinase activity (Fig. 5C, lanes 5-10) and autophosphorylation by themselves seemed to occur as we compared their electrophoretic mobilities in Fig. 5, A and $B$, and the corresponding mobilities in the anti-PY Western blot (Fig. 5C). Interestingly, in cells expressing c-JAK1 and c$\mathrm{JH}(1+2)$, an additional protein of $60 \mathrm{kD}$ was detected by anti$\mathrm{JH} 1$ antibodies and anti-PY $\mathrm{mAb}$ (Fig. 5B, lanes 7-10, and Fig. 5C, lanes 7-10). Moreover, there were more tyrosine-phosphorylated proteins bound to Ni-agarose in the Triton-insoluble fraction of insect cells expressing c-JAK1 and c-JH( $1+2)$ (Fig. 5C, lanes 8 and 10) than cells expressing C-JH1. The proteins analyzed were fractions bound to $\mathrm{Ni}$-agarose, presumably via the His-tag of recombinant proteins. Therefore, they were either cleavage products of JAK1 related proteins or associated proteins.

\section{c-JHI and c-JH2 interact with each other}

To demonstrate the association of c-JH1 and c-JH2, anti-JH1 antibody was used to precipitate c-JH1 from the extract of vAcJH1- and vAcJH2-co-infected cells, and the associated c$\mathrm{JH} 2$ was detected by blotting with anti-JH2 antibody. As shown in Fig. $6 \mathrm{~A}, \mathrm{c}-\mathrm{JH} 2$ is co-precipitated by c-JH1. Similarly, c-JH1 is also co-precipitated by c-JH2 (Fig. 6B). Because both proteins are highly expressed under these conditions, there is the possibility that this interaction is somehow nonspecific. Therefore, another recombinant baculovirus vAcCAT, which carries the chloramphenicol acetyltransferase (CAT) gene under the control of the same polyhderin promoter, was used to coinfect with vAcJH1 or vAcJH2. The immunoprecipitation data showed that neither anti-JH1 nor anti-JH2 antibody was able to precipitate CAT protein from the coinfected cell extract (data not shown). Moreover, neither anti-JH2 nor anti-JH1 antibody was able to precipitate c-JH1 or c-JH2 from the extracts from cells infected with vAcJH1 or vAcJH2 alone as shown in Fig. 6 (lane 1). Therefore, c-JH2 seems to interact specifically with c-JH1 and possibly by tyrosine-phosphorylated by c-JH1 (see texts below).

\section{$J H 2$ domain is tyrosine-phosphorylated by $c-J A K 1$ and c- $J H(1+2)$}

Because c-JH1 and c-JH2 were associated with each other (Fig. 6), we sought to investigate whether c-JH2 is a substrate for c-JH1 by co-infection experiments in which insect cells were co-infected with vAcJH2 and vAcJAK1 or vAcJH2 and $\mathrm{vAcJH}(1+2)$, instead of co-infection with $\mathrm{vAcJH} 2$ and vAcJH1. This avoided ambiguity in data interpretation due to the similar mobility of c-JH1 and c-JH2 on $\mathrm{NaDodSO}_{4}$-PAGE. The experimental procedures were the same as those described in the vAcJH1 and vAcJH2 co-infection experiment. Proteins bound to $\mathrm{Ni}$-agarose gels were analyzed by blotting with either anti-JH2 antibody or anti-PY mAb. The control experiment was carried out by infecting insect cells with either vAcJAK1 or
A

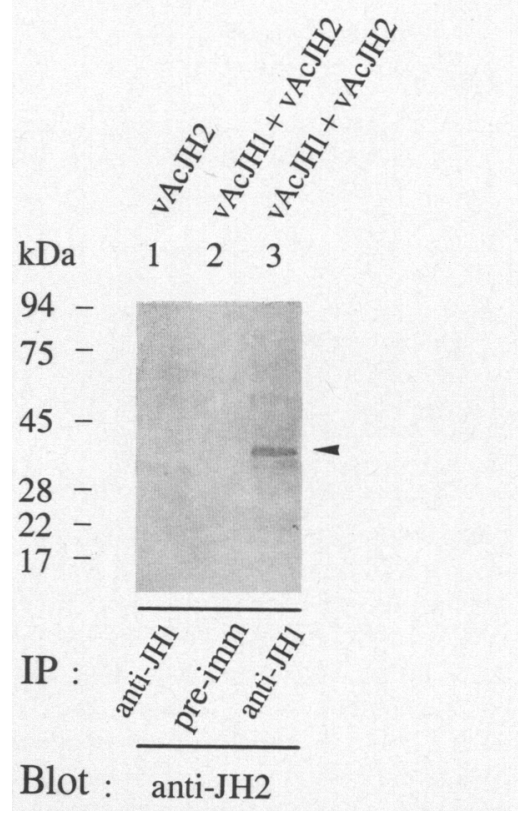

B

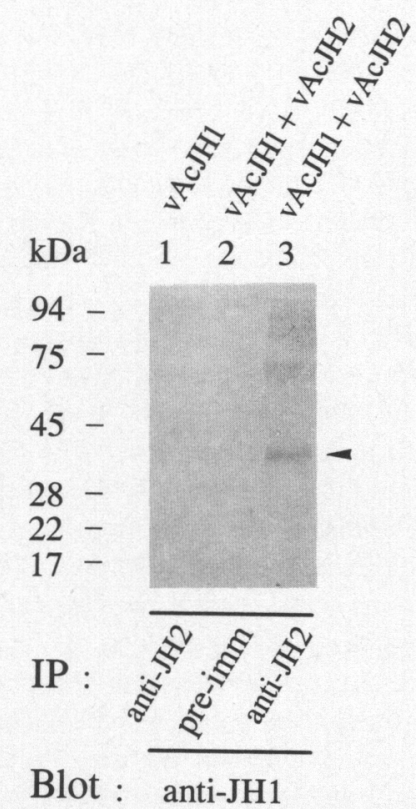

FIG. 6. Association of c-JH1 with c-JH2. Sf9 cells were infected with vAcJH2 alone (a, lane 1), vAcJH1 alone (B, lane 1), and co-infected with vAcJH1 and vAcJH2 (lanes 2 and 3), respectively. The Triton-soluble fractions were immunoprecipitated with normal guinea pig antiserum (pre-imm; lane2), anti-JH1 antibodies (A, lanes 1 and 3 ) and anti-JH2 antibodies (B, lanes 1 and 3). The associated proteins were analyzed by $\mathrm{NaDodSO}_{4}$-PAGE, transferred to nitrocellulose, and immunoblotted with antiJH2 (A) or anti-JH1 antibodies (B). Arrowhead indicates positions of c-JH1 and c-JH2, respectively. 
vAcJH $(1+2)$ alone. As shown in Fig. 7B, c-JH2 indeed was tyrosine-phosphorylated by C-JAK1 (lane 2) and by c-JH( $1+$ 2) (lane 4). This suggests that transphosphorylation of $\mathrm{c}-\mathrm{JH} 2$ by c-JH1 may occur when they are expressed in high levels together.

\section{$R T-P C R$ of brain and liver mRNA}

As described above, two overlapping clones, $\mathrm{pJ} 9$ and $\mathrm{pJ} 21$, were isolated from different tissues. To investigate whether tissue-specific alternative splicing occurs and to analyze the uncloned regions in the two tissues, five sets of specific primers were used to perform RT-PCR on mRNA derived from com-
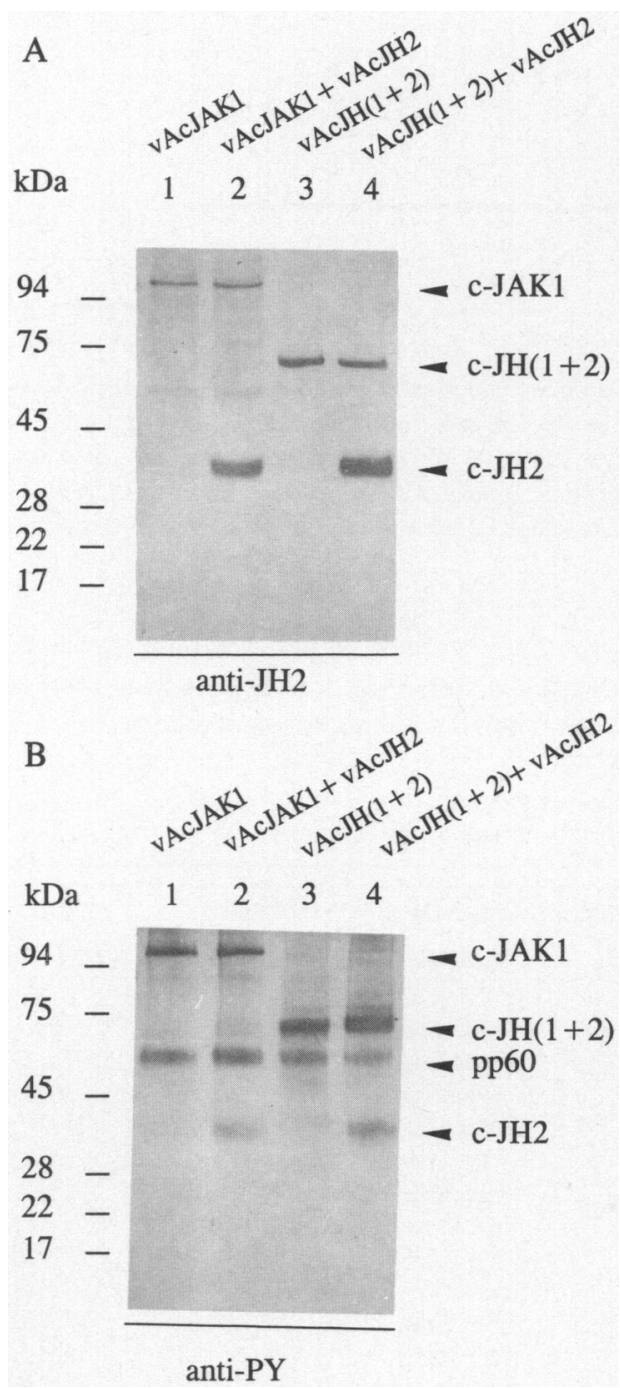

FIG. 7. Transphosphorylation of c-JH2 by c-JAK1 and cJH $(1+2)$. Sf9 cells were infected with vAcJAK1 alone (lane 1 ), both vAcJAK1 and vAcJH2 (lane 2), vAcJH(1 + 2) alone (lane 3), and both vAcJH(1 +2 ) and vAcJH2 (lane 4), respectively. The Triton-insoluble fractions were prepared and then incubated with $\mathrm{Ni}$-agarose gels and equivalent amounts of bound proteins were separated by $\mathrm{NaDodSO}_{4}$-PAGE, transferred to nitrocellulose, and immunoblotted with anti-JH2 antibodies (A) or anti-PY mAb (B). Prestained molecular mass markers (in kilodaltons) are shown on the left.

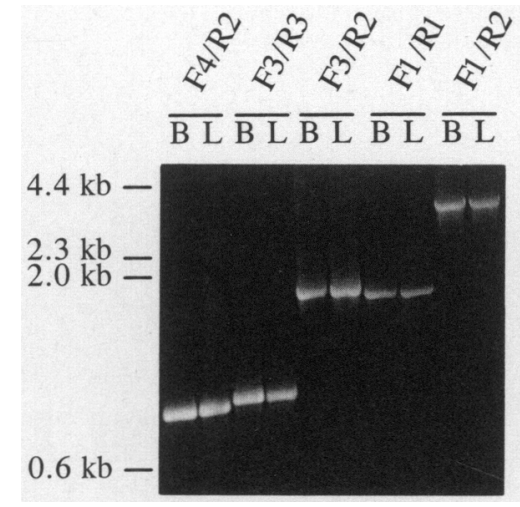

FIG. 8. RT-PCR analysis of the carp JAK1 kinase transcripts. mRNAs derived from brain (B) and liver (L) tissues were primed with oligo(dT) and random primers and subjected to reverse transcription. The resulting cDNA was amplified with five primer sets, i.e., $\mathrm{F} 3 / \mathrm{R} 3, \mathrm{R} 4 / \mathrm{R} 2, \mathrm{~F} 3 / \mathrm{R} 2, \mathrm{~F} 1 / \mathrm{R} 1$, and $\mathrm{F} 1 / \mathrm{R} 2$, and the PCR products were analyzed by electrophoresis on a $1 \%$ agarose gel. The sequence of each primer was described in the DNA Construction section.

mon carp brain and liver tissues. PCR products from both tissues were identical in length (Fig. 8). Only the uncloned regions in the two tissues, i.e., PCR products from primers F3/R3 and F4/R2 (from brain), and the DNA fragment from F1/R1 (from liver) were sequenced. All of the nucleotide sequences were the same as those we deposited in GenBank with an accession number $\mathrm{L} 24895$. These sequences, as well as those from two overlapping clones, $\mathrm{pJ} 9$ and $\mathrm{pJ} 21$, suggest that at least two identical transcripts from carp brain and liver tissues encode the same full-length carp JAK1 kinase.

\section{Genomic organization of the carp JAKI gene}

As an initial step to investigate the regulation of carp JAKI gene expression, we also cloned and characterized the carp $J A K l$ gene. Four positive phage clones, termed $\mathrm{J} 1$ to $\mathrm{J} 4$, were isolated from a Stratagene carp liver genomic library with a DIG-labeled full-length carp JAK1 cDNA as a probe. We are unable to fill the gap between phage clone J1 and J2 by PCR amplification of genomic DNA with a set of oligonucleotides that correspond to one end of clone $\mathrm{J} 1$ and the other end of clone $\mathrm{J} 2$. To locate all exons, these phage clones were analyzed by Southern blotting, subcloning, and sequencing. As shown in Fig. 9, the restriction map of each genomic clone was constructed by digesting the phage DNA with a panel of restriction enzymes separately or in various combinations: $\mathrm{Sal} \mathbf{I}, \mathbf{B g l}$ II, Hind III, Xho I, and Eco RI. On the basis of the nucleotide sequences of subcloned fragments, the carp JAKI gene is composed of 24 exons that spans at least $31 \mathrm{~kb}$ of DNA (Fig. 9). The sequences around the exon-intron boundaries were determined and are shown in Table 1. All exon-intron boundaries identified conformed to the GT/AG splice donor/acceptor rule (Breathnach et al., 1978). Some exons were relatively small (88-108 bp), whereas the first and the sixth exons were large (237 bp and $349 \mathrm{bp}$ ). The size of introns varied considerably, ranging from $>3 \mathrm{~kb}$ (intron 1) to $100 \mathrm{bp}$ (intron 19). The first exon contained the 5 ' untranslated region, and the second exon 

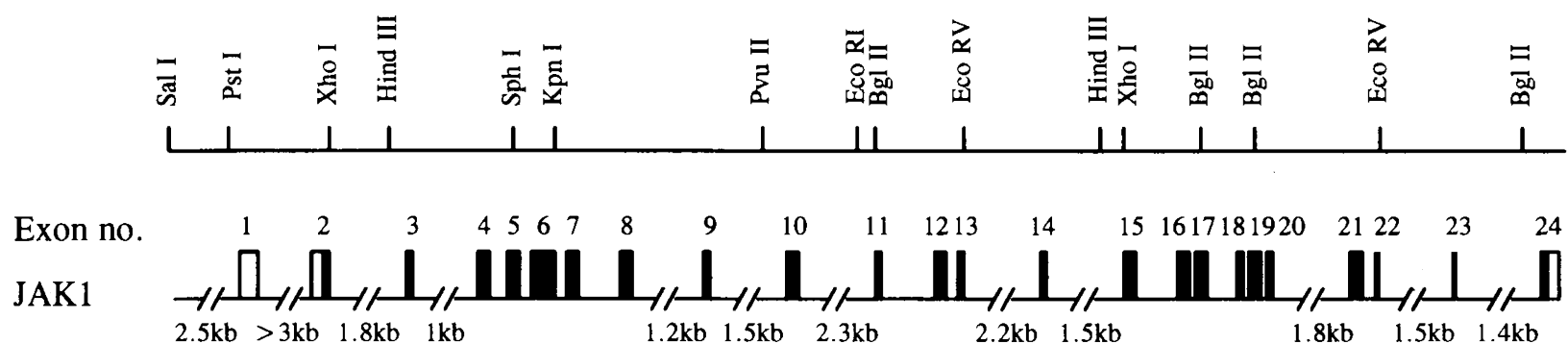

J1

11

J2

J3

J4

FIG. 9. Genomic organization of the carp JAK1 gene. Exons are indicated by boxes numbered from 1 to 24 . Solid boxes indicate the carp JAK 1 coding region whereas open boxes represent the $5^{\prime}$ and $3^{\prime}$ untranslated regions. Introns and the $5^{\prime}$ - and $3^{\prime}$ flanking regions are indicated by the solid lines. The entire gene spans at least $31 \mathrm{~kb}$ in length and contains 24 exons. A restriction map was shown above the genomic structure. Three overlapping phage clones, J2-J4 and one nonoverlapping clone, J1, were isolated from a Lambda FIXII carp genomic library. A gap between phage clones J1 and J2 was not obtainable by PCR amplification of genomic DNA.

contained the putative translation initiation site. The largest intron ( $>3 \mathrm{~kb}$ ) separates exons 1 and 2 . The $\mathrm{JH} 2$ domain was located on exons 11-17 and the catalytic JH1 domain was located on exons 18-24. Exon 24 contained the last 33 amino acids as well as the $3^{\prime}$ untranslated region. The promoter and exon/intron sequences of carp $J A K l$ kinase gene have been deposited in GenBank with 10 serial accession numbers, from U53685 to U53694.

Table 1. Exon-Intron Organization of the Carp Jak1 Gene

\begin{tabular}{|c|c|c|c|c|c|c|c|}
\hline $\begin{array}{c}\text { exon } \\
\text { number }\end{array}$ & $\begin{array}{l}\text { exon size } \\
\text { (bp) }\end{array}$ & $\begin{array}{l}\text { 3'end of } \\
\text { the exon }\end{array}$ & $\begin{array}{l}\text { 5'end of } \\
\text { the intron }\end{array}$ & $\begin{array}{c}\text { approximate } \\
\text { size (bp) }\end{array}$ & $\begin{array}{l}3 \text { 'end of } \\
\text { the intron }\end{array}$ & $\begin{array}{l}\text { 5'end of } \\
\text { the exon }\end{array}$ & $\begin{array}{l}\text { amino acid } \\
\text { interrupted }\end{array}$ \\
\hline 1 & 242 & TGC CTG ACG AG & gtaaggacga & $>3000$ & tatcctgcag & T GTC TGG ATG & \\
\hline 2 & 208 & CAA GAA GAT GCC & gtaagcgaga & 1800 & ttttccccag & ACA TCT $\overline{\mathrm{CAC}}$ & Ala67 (3) \\
\hline 3 & 125 & TAC CGT ATG AG & gtgagtgggc & 1000 & gtttacacag & G TTT TAT TTT & Arg109 (2) \\
\hline 4 & 154 & CTG TTT GCA CAG & gtgaggtaca & 400 & tatgttttag & GGC CAG TAT & $G \ln 160$ \\
\hline 5 & 164 & GCT GAG ACC AG & gtgaggtaca & 148 & atctttgtag & C TAC AAG CGA & Ser215 (2) \\
\hline 6 & 349 & AAG CCT GTA CCG & gtgagtttag & 250 & cttttgatag & AAT ATT CTG & Pro331 (3) \\
\hline 7 & 180 & AAT AAA ACT ATG & gtaatttcca & 600 & ttgcccacag & GAG TTG GAC & Met391 (3) \\
\hline 8 & 158 & GGA CCT ATC TG & gtatgaccat & 1200 & ttctctacag & C ACA GAG TAT & Cys444 (2) \\
\hline 9 & 115 & GTC TGC ATT GAG & gtacacacac & 1500 & tctctctcag & ATG GAC CTA & Glu482 (3) \\
\hline 10 & 199 & CAA CCC AGA A & gtaccagcac & 2300 & tttccttcag & AA ATT TCC AAC & Lys549 (1) \\
\hline 11 & 110 & GAG ATT GTA CAG & gtgatatttt & 900 & ttttattcag & GGT GAG CAT & Gln585 (3) \\
\hline 12 & 150 & GAT ATC TCT CTG & gtaagatgca & 187 & ctcctctcag & GCT TTC TTT & Leu635 (3) \\
\hline 13 & 89 & CAT CAG GAG AA & gtaagtacct & 2200 & ctgtctgtag & T ATC ATG GTG & Asn665 (2) \\
\hline 14 & 127 & CTC AGC TAT CTG & g taaagaaac & 1500 & aatcctgtag & GAG GAC AAG & Leu707 (3) \\
\hline 15 & 136 & AGC AGA GAA G & gttgagagat & 820 & gtgtctacag & AG TGT GTG GAC & Glu753 (1) \\
\hline 16 & 152 & AAG CTC ACA GAG & gtaacagcat & 111 & ctctgagcag & AAG GAG AGG & Glu803 (3) \\
\hline 17 & 152 & GAG AAA CAG AA & gtatgaccta & 457 & ttctctccag & T CCT TCC ATT & Asn854 (2) \\
\hline 18 & 88 & GAT CTT GGA GAG & gtattttctg & 110 & ctcttttcag & GGT CAC TTT & Glu883 (3) \\
\hline 19 & 193 & CAC GAA GAA G & gtaaagccac & 100 & ttgtttcaag & GT GGG AGA TCC & Gly948 (1) \\
\hline 20 & 125 & CAG ATC TGC CAG & gtaacatcat & 1800 & ttaactccag & GGC ATG GAC & Gln989 (3) \\
\hline 21 & 173 & CCA GTG TTC TG & gtaagaatca & 170 & attttcccag & G TAT GCC CCA & $\operatorname{Trpl047(2)}$ \\
\hline 22 & 118 & AGC CCT ATG TCG & gtaagtggcc & 1500 & aaccattcag & GTG TTC CTT & Ser1086(3) \\
\hline 23 & 111 & TGC TCA GAC AGG & gtaatatata & 1400 & gttttgacag & TTG TAC TGT & Argl123(3) \\
\hline 24 & 164 & ATG ATT GAC AAT & TAACTATGGAA & GATGAGATGCA & ACCTCTTTTGTA & $\begin{array}{l}\text { GGAAGTTCCAGAGAGA } \\
\text { ( the end of }\end{array}$ & $\begin{array}{l}\text { AAAAAAAAAAAA } \\
\text { p JAK1 gene ) }\end{array}$ \\
\hline
\end{tabular}




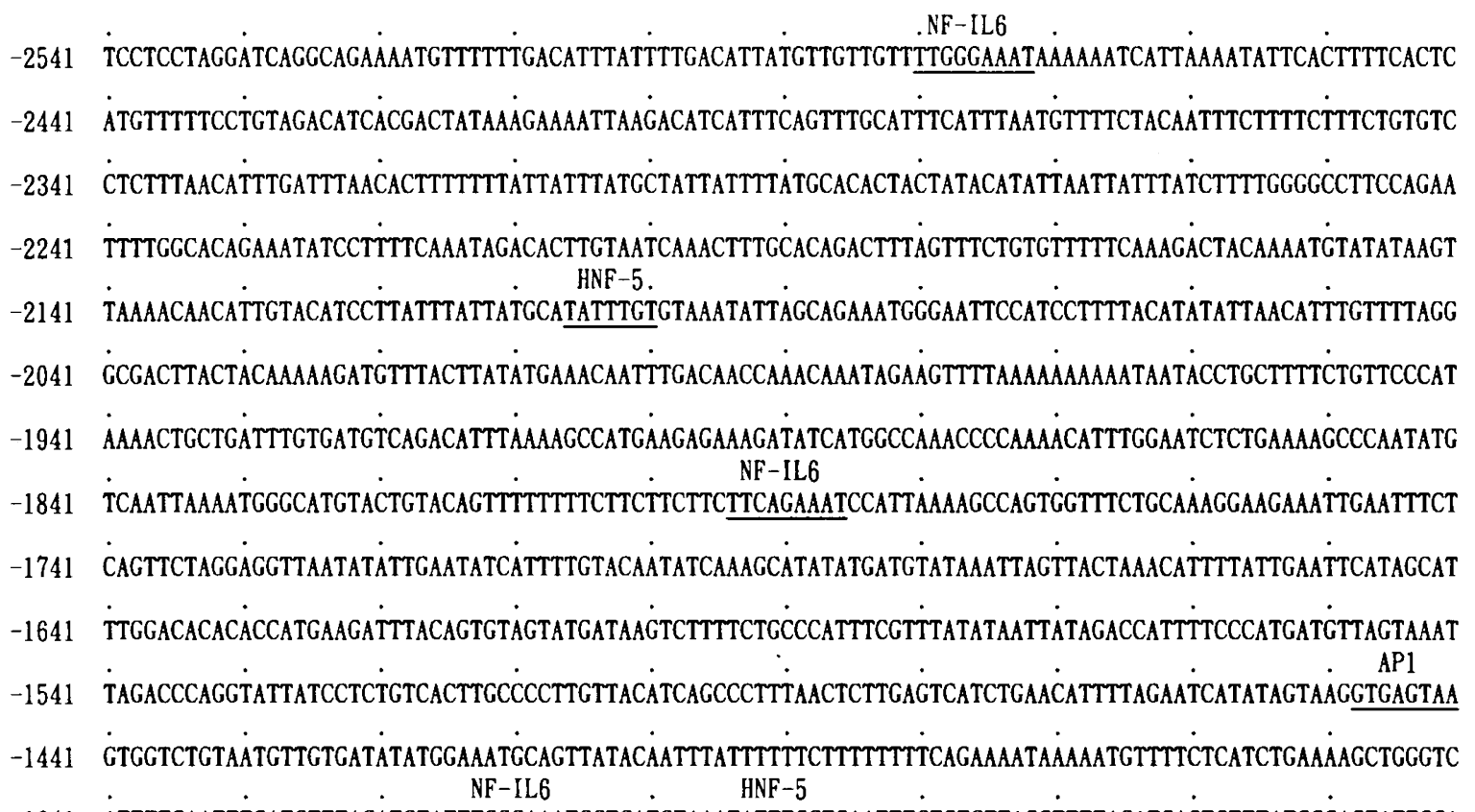

-1341 ATTTTCAATTTGATGTTTACATGTATTTGGGAAATCCTCATCTAAATATTTGCTGAATTTCTGTCTTAGCTTTTAGATGAGTGTTTATGGCAGTATTGCA

-1241 CGTAGACTCATCACGGACCAATTATAGCCCATGACTCATCCAACGATAGGAGTTTCCAACTGGACTTTTTCCCCCCAGTGTTTGTTTAAATATTATTGTC

-1141 AACATATCTCAACACCATATTTGACATAAATATGTATTGTTGCAAATCATTTTGACATGTCTGACAACATTTATATGGAAATGTTGATAAGGATAGACAA

-1041 AAATGTATTTAATAGTAGAATTTGAACTGAACGTTTTACTCTAAAAACCTATTAAACTCCAATACACACAGTCTAATATTGTTTATATATCTACCCGAAC

-941 TTCTGTTGAACTTATTGATCAGTCACATTCTCCCAATGCTCTGCAGCCCACAGTTTCTGGCAACTCATATGATGCTGAGGACGGAAGTCCCTCCCTTTCA

-841 CGGCAGGCTTAAACCTCATGTCTTAAAGACCATCTGCGTAATCAGAGAGGGGTTTGTGTTTTGCTGATACCTATTTTAAAAACAGACACGTACCTGTAAA

-741 GCGGAAACAGCTGATTGATTAACTTAATGTTTAGGATTAGGACTTTATGGACAAAAATAAACAACAGTAATAAAATGTAACAGTTCATTMATAATATTTC

-641 TATTTACATTTTATTTCTGAAATCTAAATTATTTATGATTATATCCATTATTTATGAATCTGCAAAACATCTTTTACAGTGTTGTGCTGTTACTGTTTAT

-541 ATAGACTAGATAACTGCAGTATCTAAGCGTTACTTTTAAATGAGAAGCATAATAATGGTTAGTTAGCAGTAATTATTTAATATATGAATCAATTATTAAT

-441 GCTTGTTATATTTAAAGTGGTCATGTGGCATACCATTCAATGGACAAAATTTTATCCGAGATATCTTTTTAATACTACATATTTAACGAAGTGAAATCAG

-341 CGCTTAAGGATCTTCATGTATTATGATTGTAATCATTTTCAAACCATTTGAATCATTGGAGAGAGAGAAAAAAAAATGATATGTATAAATATGATGTTTT

-241 GGGAAATTTATGCATTTATGTTTACATTACAGCAATGCACTCTAAGCGAGAGTTTTGATCGCATGCATAAATAGTAATTCGTCTTTTAACTATATACAGT

-141 ACAGAGGCAATGCGTGCAGTAGCCACAACAAAAAATCGCTGGCTTACTCTCTGCTTAAGGGTTAAAGCCATTGGTACAGAATTTGATTGACAGCCGCATG . CCAAT .

-41 AGCCAATAAGCGGCATGTTACAGACCTCGTCGTTACCCTATTTTCGGGAATGTGTTCGACGCTTGACAGGAAAGGTTAGTTGATCATGACGACTGAAGCA

. . . . ( transcription start si te of carp JAKl gene ) .

+60 CGGTTTGTAGCACTGTGAAGTGAAGTTTGTTTTGAAAATAAACCTCGTGGAATAAACCATTATACTATCGGAGATTATTTTGGAGTGAAATAACGAGCAC

+160 TTTTACATCAACAAAAAACCAAGAGGAAGTGTTCAAACGTCTGTAATGATCGAAATTAAACGGAAGTAGCTTTGCCTGACGAGTGTCTGGATGCCAGAAC

( translation start site)

FIG. 10. Nucleotide sequence of the 5 '-flanking region of the carp JAK1 gene. A 28-mer antisense oligonucleotide used for primer extension analysis is underlined. The candidate transcription start site by primer extension (see Fig. 11) is indicated with a nucleotide number $(+1)$ and an asterisk, which is located at 249 bp upstream to the translation start site. Potential binding sites for a variety of transcription factors are also marked and underlined. The promoter and exon 1 sequences of carp JAK1 kinase gene has been deposited in GenBank, accession number U53685.

Determination of the transcription initiation site

The transcription start site was determined by primer extension analysis using poly $(\mathrm{A})^{+}$RNA from carp liver. We used a 28 -mer oligonucleotide labeled with ${ }^{32} \mathrm{P}$ at the $5^{\prime}$ end. The ex- act position of the extended product was determined by aligning the sequencing ladder obtained with the same primer. One major extended product was revealed and corresponded to the site at $249 \mathrm{bp}$ upstream to the initiator methionine codon. For describing the $5^{\prime}$-flanking region of the carp $J A K 1$ gene, we 
used a numbering scheme that the transcription start site of the carp JAK kinase gene is designated +1 (Fig. 10).

\section{Characteristics of the 5'-flanking region of the carp JAKl gene}

To identify sequence elements possibly involved in the control of carp $J A K 1$ gene expression, the 2.8 -kb DNA fragment of the $5^{\prime}$ upstream region of the $J A K 1$ gene relative to the translation start site was sequenced and shown in Fig. 11. Computer analysis of the sequence revealed numerous potential binding sites for transcription factors. One TATA box (TATAAA), which is generally located at a position around $30 \mathrm{bp}$ upstream to the RNA start site (Breathnach and Chambon, 1981), is observed at 253 bp upstream to the RNA start site. Thus, the carp $J A K l$ gene promoter belongs to the subclass of TATA-less RNA polymerase II promoters that are found in many protein tyrosine kinase genes (Patel et al., 1990; Lichtenberg et al., 1992; Uchiumi et al., 1992; Kawagishi et al., 1995; PerezCastro et al., 1995; Sideras et al., 1994). This gene also has a CCAAT box at -35 to -40 relative to the RNA start site, however, not at the standard positions between -60 and -80 relative to the RNA start site (Chodosh et al., 1988). Two putative binding sites for HNF-5 (Grange et al., 1991) are present at $-2,107$ and $-1,295$. Other potential binding sites for a ubiquitously expressed transcription factor, NF-IL6 (Akira et al., 1990 ), are observed at $-2,481,-1,795,-1,315,-627$, and -243 . It has been shown that genes containing the NF-IL6 binding site are induced during inflammation (Akira et al., 1994). Moreover, the proto-oncogene product E2A (Murre et al., 1989) binding site is found at -735 . A site for GHF-5 (Schaufele $e t$ al., 1990), a ubiquitous gene activator that is induced in response to various extracellular signals, is found at position -601 . The flanking region also contains DNA motifs for AP1 (Lee et al., 1987) at $-1,449$ and $-1,211$.

\section{Functional analysis of the 5'-flanking region}

To verify whether the $5^{\prime}$-flanking region of the carp JAK 1 kinase gene exhibits functional promoter activity, the genomic DNA fragment containing the $5^{\prime}$-upstream region $(-2,541$ to +59 ) was fused to the CAT reporter gene in pCAT-Basic to create pJP1-CAT (Fig. 12). Following transfection into carp CF cells (Chen and Kou, 1986), this chimeric gene produced about 16 times of the promoter activity of the pCAT-Basic, indicating that this fragment contains a functional eukaryotic promoter. A series of $5^{\prime}$ deletion mutants were then created from pJP1CAT and analyzed. As shown in Fig. 12, the promoter activity of pJP4 $(-1,023$ to +59$)$ was the same as that of pJP1 $(-2,541$ to +59 ). This indicates that deletion of the region between $-2,541$ and $-1,023$ did not have a detrimental effect on promoter activity. However, two further deletion mutants, pJP5 $(-528$ to +59$)$ and pJP6 $(-181$ to +59$)$, displayed significant loss of promoter activity that were about seven and six times of the promoter activity of the pCAT-Basic, respectively. This suggests that a positive enhancer element is located between $-1,023$ and -528 . Interestingly, the minimal promoter element $(-181$ to +59$)$ does not contain any typical TATA-box sequences or $\mathrm{G}+\mathrm{C}$-rich sequences associated with many promoters. In addition, other deletions without this region, pJP2

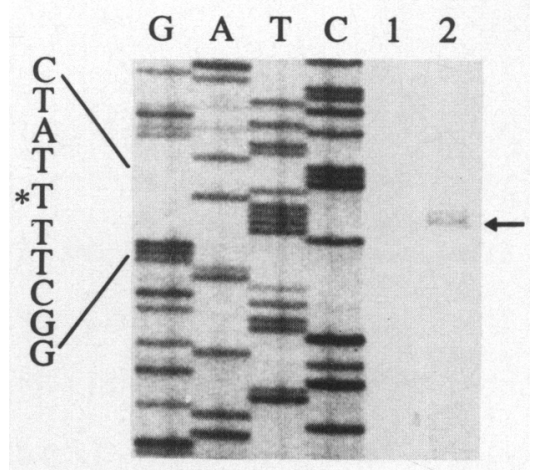

FIG. 11. Determination of the transcription initiation site of the carp JAK1 gene. ${ }^{32} \mathrm{P}$-labeled primer (see Fig. 10) was annealed to $10 \mu \mathrm{g}$ of yeast tRNA (lane 1 , as a negative control) or $5 \mu \mathrm{g}$ poly(A) ${ }^{+}$RNA from carp liver (lane 2) and extended with reverse transcriptase. The sequencing ladder of the carp JAK1 gene labeled $\mathrm{G}, \mathrm{A}, \mathrm{T}$, and $\mathrm{C}$ was obtained by using the same primer and electrophoresed on the same gel. The extended product and its position relative to the initiator ATG codon are indicated.

$(-2,541$ to -181$)$ and pJP3 (-2,541 to -901$)$, resulted in a severe loss in promoter activity and the activity was the same as that of the promoterless control.

\section{DISCUSSION}

We have cloned a 3.7-kb cDNA that encodes carp JAK1 of 1,156 amino acids. The encoded protein has the characteristic kinase-like (JH2) and kinase (JH1) domains shared by all JAK family members. This clone has the highest sequence homology with mammalian JAK1, especially in the JH1 and JH2 domains (70\% identity). The overall amino acid sequence identity between carp JAK1 and other JAK family members are: $57 \%$ (murine JAK1), 35\% (murine JAK2), 31\% (murine JAK3), and $42 \%$ (human Tyk2). On the basis of these homologies, we name this clone as carp JAK1.

The full-length clone of the carp JAK 1 cDNA was not directly isolated by library screening, but was constructed from clones isolated from two different tissues. However, it represents the true carp JAK 1 cDNA because we have employed RTPCR to obtain the uncloned regions in the brain and liver tissues. The nucleotide sequences of the uncloned region in the brain were the same as those in clone $\mathrm{pJ} 21$ (isolated from a liver cDNA library). Similarly, the nucleotide sequences of the uncloned region in the liver were the same as those in clone pJ9 (isolated from a brain cDNA library). This also suggests that tissue-specific splicing does not occur in brain and liver tissues.

The baculovirus expression system has been used to express mammalian JAK2 kinase (Quelle et al., 1994; Duhe and Farrar, 1995), and it appears that JAK2 kinase autophosphorylates and becomes activated when overexpressed in insect cells. In this report, all of the recombinant proteins, such as full-length carp JAK1 (c-JAK1), the JH1 (c-JH1), and combined JH2/JH1 [c$\mathrm{JH}(1+2)]$, can display tyrosine kinase activity and selfautophosphorylation (Fig. 5C, lanes 5-10). It appears that once 
kinase production exceeds a critical level, monomers of the kinase begin to form catalytically competent oligomers and then tyrosine autophosphorylation occurs spontaneously (Duhe and Farrar, 1995).

The JAK kinase members lack SH2 and SH3 domains, but contain a unique JH2 domain (Ziemiecki et al., 1994). The functions of the JH2 domain are still unknown. In this study we have attempted to address this issue by using carp JAK1 as a model. Co-infection and immunoprecipitation data indicate that
c-JH1 and c-JH2 associate with each other (Fig. 6). In addition, c-JH2 can be tyrosine-phosphorylated by c-JAK1 and by c$\mathrm{JH}(1+2)$ (Fig. 7). This strongly suggests that the transphosphorylation does occur and $\mathrm{c}-\mathrm{JH} 2$ is the potential substrate for c-JAK1, c-JH $(1+2)$. The results also raise some questions. Is JH2 domain phosphorylated by the JAK kinases in cytokinemediated signaling as we have observed in insect cells? What are the nature and relevance of c-JH2 tyrosine phosphorylation? Are these phosphorylation sites playing important roles in re-

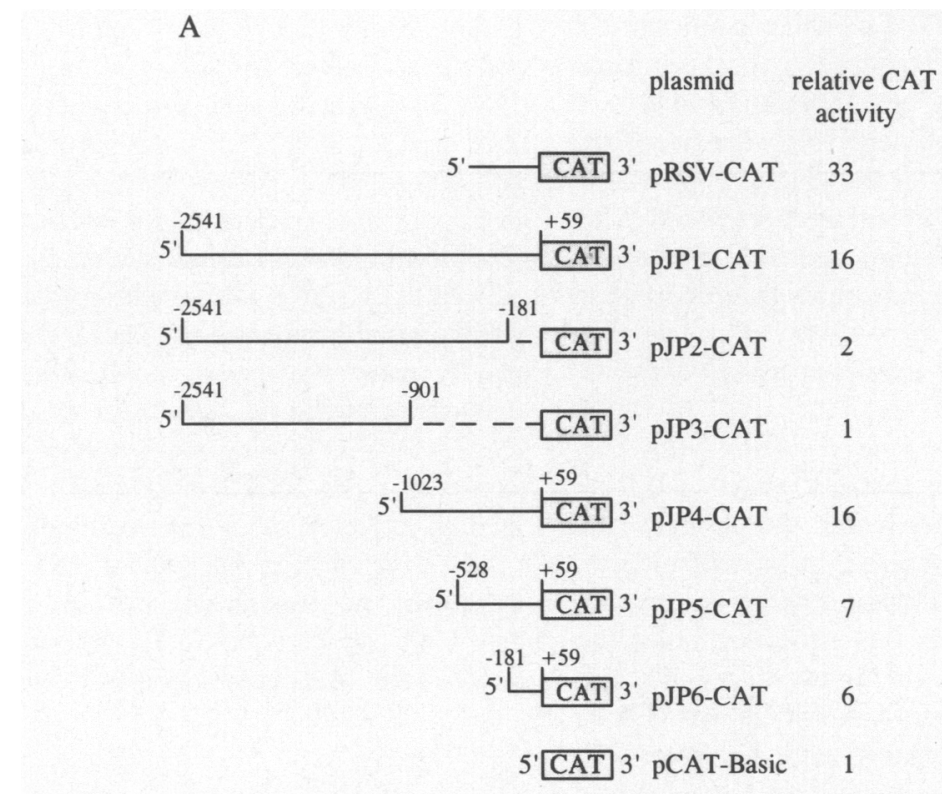

B

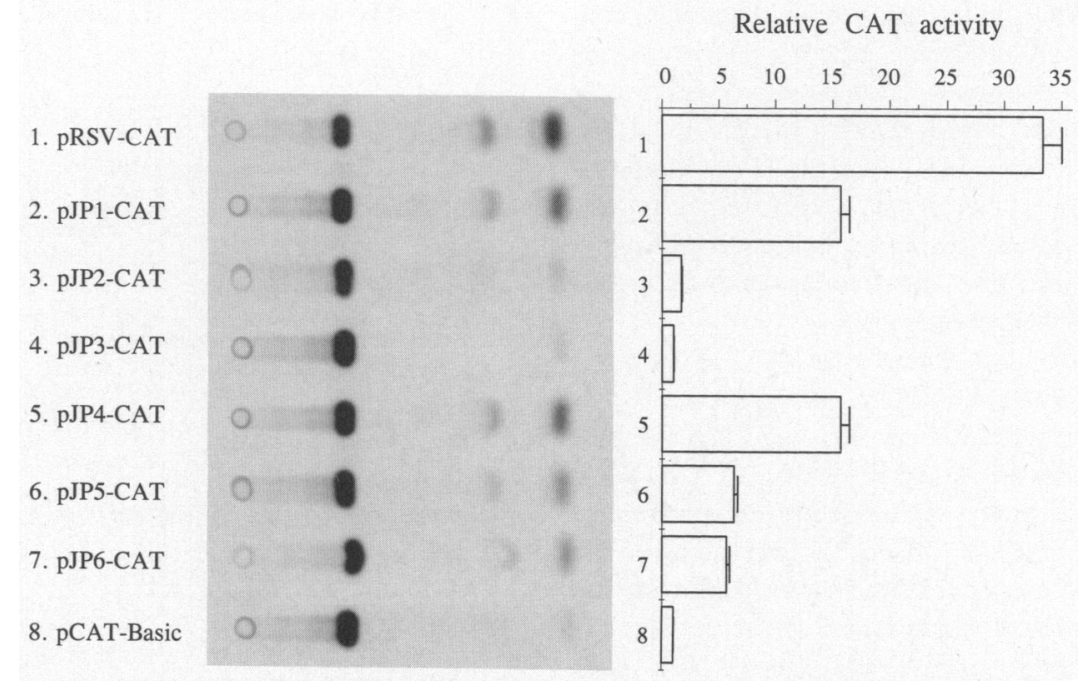

FIG. 12. Analysis of the promoter activity of the 5'-flanking region of the carp JAK 1 gene fused to the CAT reporter gene. A. Schematic representation of various CAT transient expression constructs. DNA constructs are shown relative to the promoterless vector pCAT-Basic with the CAT gene depicted as an open box. Various lengths of the 5'-flanking region of the gene were fused with the CAT gene in pCAT-Basic (see Materials and Methods). B. Chimeric genes with different promoter activities. Each chimeric gene was cotransfected with pSV- $\beta$-Gal DNA into CF cells and assayed for CAT and $\beta$-Gal activities as described in Materials and Methods. CAT activity in an individual experiment was corrected for variation in transfection efficiency by normalizing the value to the $\beta-\mathrm{Gal}$ activity in the same extract. The normalized activity of each promoter construct was then expressed relative to that of pCAT-Basic, with pCAT-Basic assigned a relative activity of 1.0. The data represented the mean of triplicate transfection experiments for each plasmid. 
cruiting additional signalling proteins to the cytokine receptor complex? Identification and characterization of tyrosine phosphorylation sites in $\mathrm{c}-\mathrm{JH} 2$ are currently under investigation. The transphosphorylation between mammalian JAK kinases has been reported in a recent study on the interferon- $\gamma$ signal transduction in which JAK2 can phosphorylate itself and JAK1 (Briscoe et al., 1996). However, which domain of the JAK kinases is involved in this transphosphorylation is unknown. Therefore, our results may provide some information regarding this issue.

In cells expressing c-JAK1 and c-JH( $(1+2)$, a $60-\mathrm{kD}$ protein (pp60) was detected by anti-JHl antibodies and by anti-PY mAb (Fig. 5B, C, lanes 7-10). Although pp60 may be a degradation product of c-JAK1 or c-JH(1 +2$)$, pp60 could also be detected in the cell extract when insect cells were coinfected with vAcJH1 and vAcJH2 (data not shown). As reported recently, a relatively similar $62-\mathrm{kD}$ protein has been found in the truncated rJAK2 immunoprecipitation complex (Duhe and Farrar, 1995). These two proteins are possibly the same protein that may be virally encoded or may be a Sf9 cellular product.

The association of an increased number of phosphotyrosinecontaining proteins with c-JAK1 and $\mathrm{cJH}(1+2)$ (Fig. 5C) poses some intriguing questions. Are these proteins specifically associated with $\mathrm{Ni}$-agarose or are proteins bound to the $\mathrm{Ni}$ agarose phosphorylated to a greater extent. The proteins analyzed were fractions bound to $\mathrm{Ni}$-agarose, presumably via the his-tag of recombinant proteins. If the former is correct, one might expect that those proteins are $\mathrm{JH} 2$-associated molecules. By contrast, an alternative explanation for the latter is that $\mathrm{JH} 2$ activates $\mathrm{JH} 1$, which indiscriminately phosphorylates cellular proteins resulting in nonspecific binding to the $\mathrm{Ni}$-agarose. To test the possibility, Sf9 cells were infected with recombinant baculovirus, which contains truncated human insulin receptor gene (Villalba et al., 1989). In the cell extract, there were constitutively active truncated insulin receptor and many tyrosinephosphorylated proteins. However, these proteins could not be precipitated by $\mathrm{Ni}$-agarose (data not shown). Therefore, the possibility that high numbers of c-JAK1- and c-JH(1 + 2)-associated proteins could be an artifact of the Ni-agarose column was ruled out. At present, we do not know how c-JAK1 and c$\mathrm{JH}(1+2)$ associate with those tyrosine-phosphorylated proteins and this awaits further investigation.

In this study, we have also cloned at least $31 \mathrm{~kb}$ of a genomic region containing the carp $J A K I$ gene. This gene consists of 24 exons that average $158 \mathrm{bp}$ in size and 23 introns that range from $100 \mathrm{bp}$ (intron 19 ) to $>3 \mathrm{~kb}$ (intron 1 ).

The first intron interrupts the corresponding $5^{\prime}$ untranslated region of the carp $J A K I$ mRNA sequence. Thus, not all of the exons contain translated sequences. An untranslated exon 1 is also found in many protein tyrosine kinase genes, such as the human LCK gene (Rouer et al., 1989), mouse $H C K$ gene (Ziegler et al., 1991), mouse fibroblast growth factor receptor 3 gene (Perez-Castro et al., 1995), human a-platelet-derived growth factor receptor gene (Kawagishi et al., 1995), and human Bruton's agammaglobulinemia tyrosine kinase gene (Sideras et al., 1994).

The members of the JAK kinase family lack SH2 and SH3 domains, but contain a unique $\mathrm{JH} 2$ domain (Ziemiecki et al., 1994). Although the JH2 domain contains all the hallmarks of a protein kinase, its amino acid sequence differs significantly from that of the kinase-catalytic (JH1) domain (Fig. 13). In this study, we show that the locations of intron-exon boundaries in the $\mathrm{JH} 2$ domain are also different from that of the $\mathrm{JH} 1$ domain (Fig. 13). This suggests that the JH2 domain may not be derived from the $\mathrm{JH} 1$ domain by simple duplication.

On the basis of the sequence homology in the kinase domain, the nonreceptor PTKs are first divided into the Src, Fes/Fer, Abl/Arg, and JAK families (Hanks, 1991). Recently, other families such as Csk, Btk/Itk/Tec, Syk/Zap70, and FAK families are also included (Ziemiecki et al., 1994). The complete genomic structures of some of them are known. Within the Src family, the genomic structures of $S r c, F g r, H C K$, and $L C K$ are completely solved (Anderson et al., 1985; Nishizawa et al., 1986; Tanaka et al., 1987; Rouer et al., 1989; Patel et al., 1990; Ziegler et al., 1991). The intron-exon boundaries in the kinase domains are highly conserved among these members. As shown in Fig. 14, the locations of intron-exon boundaries in the kinase domain within several subfamilies of nonreceptor PTKs as well as carp JAK1 kinase are presented schematically. The intron-exon organization of carp JAK1 kinase is different from that of other nonreceptor PTKs. One exception is that the boundary between the carp JAK1 exons 18 and 19 within the consensus ATP-binding motif (Gly-X-Gly-X-X-Gly) is at the same site in Fes. This observation is consistent with the classification of JAKs into a separate family of nonreceptor PTKs.

The expression of mammalian JAK1, JAK2, and TYK2 is ubiquitous, whereas that of JAK3 is mainly in hematopoietic cells (Ihle and Kerr, 1995). To understand the possible regulation of carp $J A K I$ gene expression, we have mapped its tran-

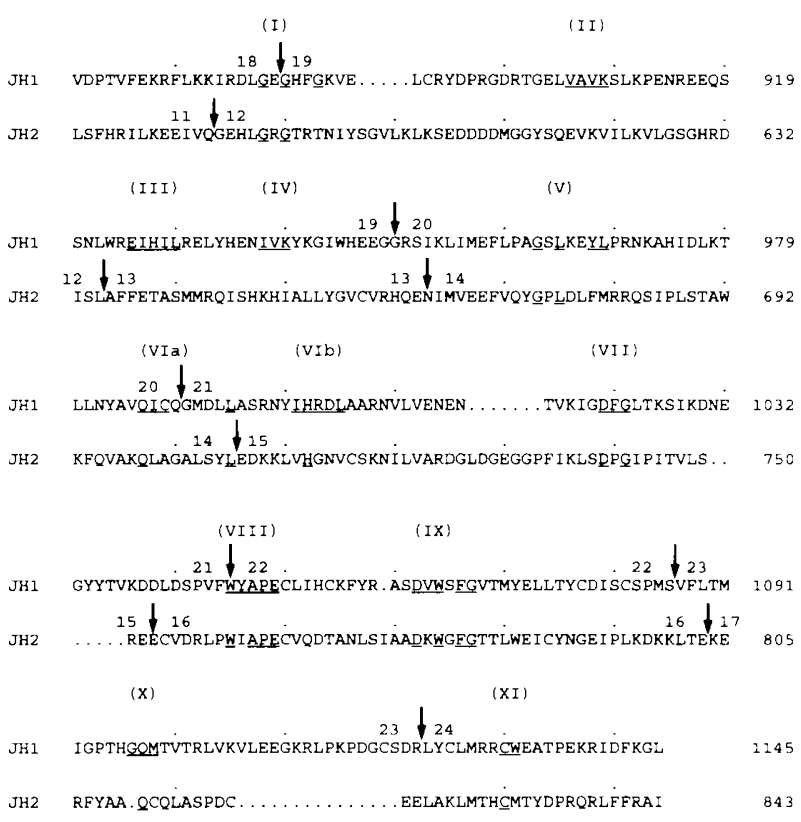

FIG. 13. Amino acid comparison and positions of the splice sites of the $\mathrm{JH} 1$ domain and $\mathrm{JH} 2$ domain of the carp JAK1 kinase. Numbers I-XI indicate 11 subdomains in the kinase domain as defined by Hanks (1991). Dots are introduced to optimize alignment. Splice positions are indicated by arrows with corresponding exon numbers. The PTK domain consensus sequences are underlined. 


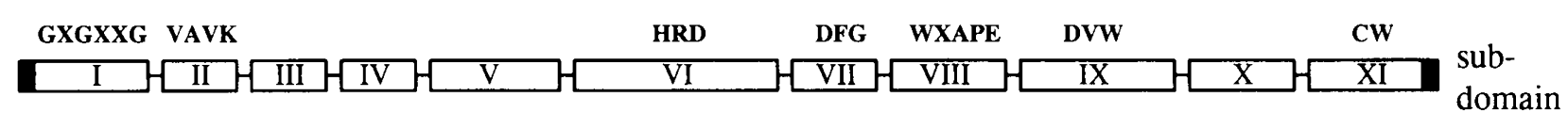

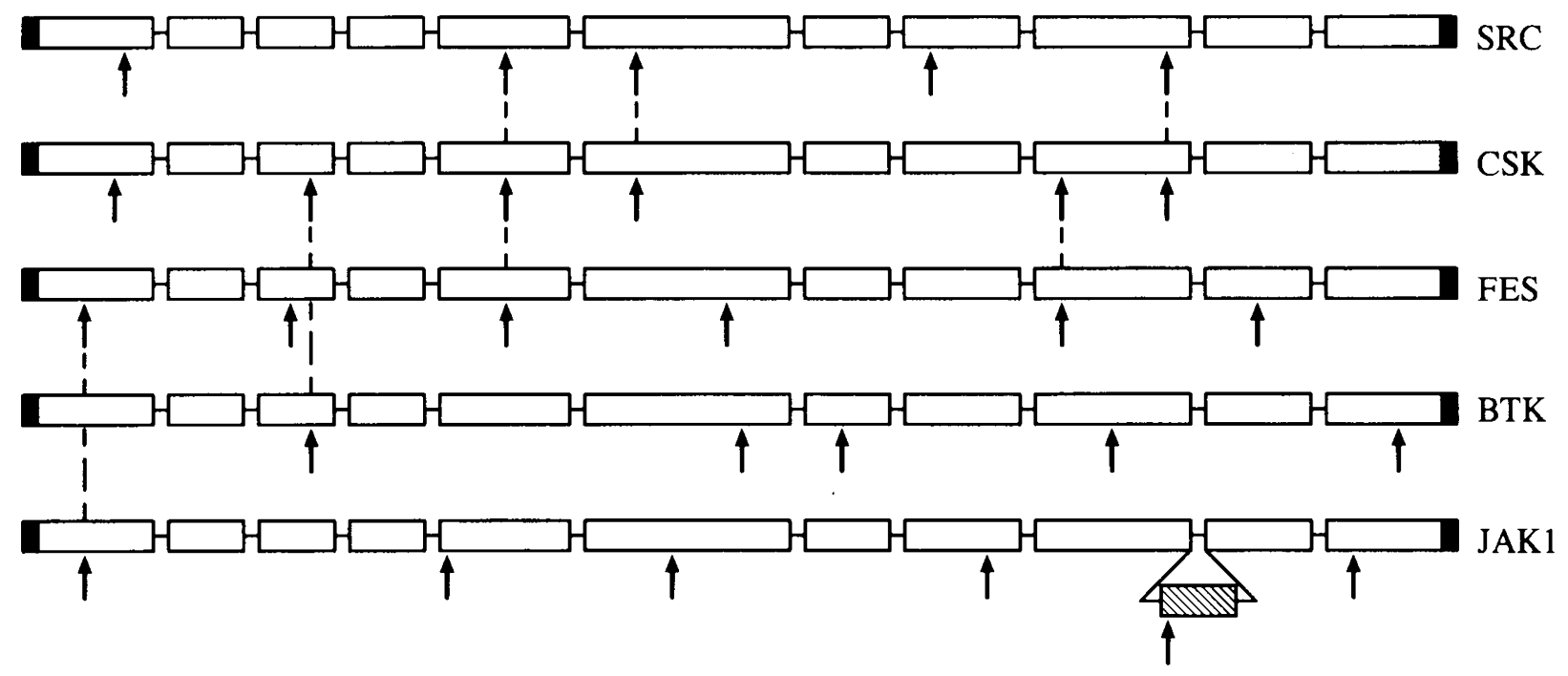

FIG. 14. Schematic comparison of the intron-exon boundaries in the kinase-catalytic domain of representative members of five subfamilies of nonreceptor PTKs. The kinase domain is divided into 11 subdomains as defined by Hanks (1991). The kinase domain of the carp JAK1 kinase has an insertion of 15 amino acid residues between subdomains IX and X. The amino acid sequences of the kinase domain of c-Src (Anderson et al., 1985; Tanaka et al., 1987), Csk (Brauninger et al., 1993), Fes (Jucker et al., 1992), Btk (Sideras et al., 1994), and carp JAK1 were compared and the consensus sequence was shown on the top of the figure. Arrows indicate the location of exon boundaries. Vertical dotted lines indicate the boundaries that are found at the same corresponding position.

scription initiation site and characterized the promoter region. Primer extension reactions revealed that the putative transcription initiation site is 249 bp upstream of the translation initiation site. The putative carp $J A K I$ promoter confers the transcription-promoting activity when placed in front of a CAT reporter gene. The deletion mutant study defined a positive regulatory region between $-1,023$ and -528 because its deletion decreased the CAT activity (Fig. 12). Some potential transcription factor binding sites are present in the carp $J A K 1$ promoter region, i.e., AP1, E2A, GHF-5, HNF-5, and NF-IL6. However, their functional relevance awaits further characterization.

The promoter of carp $J A K 1$ gene is unique when compared with other PTKs, because of promoters of receptor PTKs such as platelet-derived growth factor receptor (Kawagishi et al., 1995) and fibroblast growth factor receptor 3 (Perez-Castro et al., 1995), or nonreceptor PTKs such as HCK (Lichtenberg et al., 1992), c-fgr (Patel et al., 1990), lyn (Uchiumi et al., 1992), and $B t k$ (Sideras et al., 1994) do not contain TATA or CAAT boxes but have multiple SP1 sites and multiple transcriptional initiation sites. The smaller region $(-181$ to +59$)$ of carp promoter does not contain typical TATA-box sequences, $\mathrm{G}+\mathrm{C}$ rich sequences, or other binding sequences for known transcription factors. However, this region still has promoter activity. Therefore, some important elements that regulate the expression of carp $J A K 1$ gene may be present in this region and are needed to be characterized.

\section{ACKNOWLEDGMENTS}

We are grateful to Dr. Hsing-Jien Kung for critically reading the manuscript and encouragement. We also thank Drs. Jeffrey Jong-Young Yen and Hsin-Fang Yang-Yen for helpful discussions and advice. We also acknowledge Mr. Shui-Tsung Chen for his excellent technical assistance in raising polyclonal antibodies. We are grateful to Dr. Chu-Fang Lo for providing recombinant baculovirus vAcCAT.

This work was supported by National Science Council grants NSC-82-0203-B-001-119, NSC-83-2321-B-001-072 and NSC-85-2311-B-001-046 (to C.J. Huang) and Department of Health grants DOH82-HR-C08 and DOH85-HR-507 (to C.K. Chou).

\section{REFERENCES}

AKIRA, S., ISSHIKI, H., SUGITA, T., TANABE, O., KINOSHITA, S., NISHIO, Y., NAKAJIMA, T., HIRANO, T., and KISHIMOTO, T. (1990). A nuclear factor for IL-6 expression (NF-IL6) is a member of a C/EBP family. EMBO J. 9, 1897-1906.

AKIRA, S., NISHIO, Y., INOUE, M., WANG, X., WEI, S., MATSUSAKA, T., YOSHIDA, K., SUDO, T., NARUTO, M., and KISHIMOTO, T. (1994). Molecular cloning of APRF, a novel IFN-stimulated gene factor 3 p91-related transcription factor involved in the gp130-mediated signaling pathway. Cell 77, 63-71.

ANDERSON, S.K., GIBBS, C.P., TANAKA, A., KING, H.J., and FU- 
JITA, D.J. (1985). Human cellular src gene: Nucleotide sequence and derived amino acid sequence of the region coding for the carboxy-terminal two-thirds of pp60c-src. Mol. Cell Biol. 5, 1122-1129.

ARGETSINGER, L.S., CAMPBELL, G.S., YANG, X., WITTHUHN, B.A., SILVENNOINEN, O., IHLE, J.N., and CARTER-SU, C. (1993). Identification of JAK2 as a growth hormone receptorassociated tyrosine kinase. Cell 74, 237-244.

BACON, C.M., McVICAR, D.W., ORTALDO, J.R., REES, R.C., O'SHEA, J.J., and JOHNSTON, J.A. (1995). Interleukin 12 (IL-12) induces tyrosine phosphorylation of JAK2 and TYK2: Differential use of Janus family tyrosine kinases by IL-2 and IL-12. J. Exp. Med. 181, 399-404.

BERNARDI, G., D'ONOFRIO, G., CACCIO, S., and BERNARDI, G. (1993). Molecular phylogeny of bony fishes, based on the amino acid sequence of the growth hormone. J. Mol. Evol. 37, 644-649.

BRAUNINGER, A., KARN, T., STREBHARDT, K., and RUBSAMEN-BREATHNACH, R., BENOIST, C., O'HARE, K., GANNON, F., and CHAMBON, P. (1978). Ovalbumin gene: Evidence for a leader sequence in MRNA and DNA sequences at the exonintron boundaries. Proc. Natl. Acad. Sci. USA 75, 4853-4857.

BRAUNINGER, A., KARN, T., STREBHARDT, K., and RUBSAMEN-WAIGMANN, H. (1993). Characterization of the human CSK locus. Oncogene 8, 1365-1369.

BREATHNACH, R., and CHAMBON, P. (1981). Organization and expression of eukaryotic split genes coding for proteins. Annu. Rev. Biochem. 50, 349-383.

BRISCOE, J., ROGERS, N., WITTHUHN, B.A., WATLING, D., HARPUR, A.G., WILKS, A.F., STARK, G.R., IHLE, J.E., and KERR, I.M. (1996). Kinase-negative mutants of JAK1 can sustain interferen- $\gamma$-inducible gene expression but not an antiviral state. EMBO J. 15, 799-809.

CAMPBELL, G.S., ARGETSINGER, L.S., IHLE, J.N., KELLY, P.A., RILLEMA, J.A., and CARTER-SU, C. (1994). Activation of JAK2 tyrosine kinase by prolactin receptors in $\mathrm{Nb}_{2}$ cells and mouse mammary gland explants. Proc. Natl. Acad. Sci. USA 91, 5232-5236.

CHANG, Y.S., LIU, C.S., HUANG, F.L., and LO, T.B. (1992a). The primary structures of growth hormones of three cyprinid species: Bighead carp, silver carp, and grass carp. Gen. Comp. Endocrinol. 87, 385-393.

CHANG, Y.S., HUANG, F.L., and LO, T.B. (1992b). Molecular cloning of silver carp and bighead carp prolactin. Gen. Comp. Endocrinol. 87, 260-265.

CHEN, S.N., and KOU, G.H. (1986). Establishment, characterization and application of 14 cell lines from warm-water fish. In Invertebrate and Fish Tissue Culture. E. Kurstak and Y. Kuroda, eds. (Japan Societies Press, Springer-Verlag) pp. 218-227.

CHODOSH, L.A., BALDWIN, A.S., CARTHEW, R.W., and SHARP, P.A. (1988). Human CCAAT-binding proteins have heterologous subunits. Cell 53, 11-24.

CHOMCZYNSKI, P., and SACCHI, N. (1987). Single-step method of RNA isolation by acid guanidinium thiocyanate-phenol-chloroform extraction. Anal. Biochem. 162, 156-159.

DARNELL, J.E., JR., KERR, I.M., and STARK, G.R. (1994). JakSTAT pathways and transcriptional activation in response to IFNs and other extracellular signaling proteins. Science 264, 1415-1421.

DASILVA, L., ZACK HOWARD, O.M., RUI, H., KIRKEN, R.A., and FARRAR, W.L. (1994). Growth signaling and JAK2 association mediated by membrane-proximal cytoplasmic regions of prolactin receptors. J. Biol. Chem. 269, 18267-18270.

DUHE, R.J., and FARRAR, W.L. (1995). Characterization of active and inactive forms of the JAK2 protein-tyrosine kinase produced via the baculovirus expression vector system. J. Biol. Chem. 270, 23084-23089.

FIRMBACH-KRAFT, I., BYERS, M., SHOWS, T., DALLAFAVERA, R., and KROLEWSKI, J.J. (1990). Tyk2, prototype of a novel class of non-receptor tyrosine kinase genes. Oncogene 5, 1329-1336.

FRANKEL, S., SOHN, R., and LEINWAND, L. (1991). The use of sarkosyl in generating soluble protein after bacterial expression. Proc. Natl. Acad. Sci. USA 88, 1192-1196.

GORMAN, C., PADMANABHAN, R., and HOWARD, B.H. (1983), High efficiency DNA-mediated transformation of primate cells. Science 221, 551-553.

GRANGE, T., ROUX, J., RIGAUD, G., and PICTET, R. (1991). Celltype specific activity of two glucocorticoid responsive untis of rat tyrosine amino-transferase gene is associated with multiple binding sites for C/EBP and a novel liver-specific nuclear factor. Nucleic Acids Res. 19, 131-139.

HANKS, S.K. (1991). Eukaryotic protein kinases. Curr. Opin. Struct. Biol. 1, 369-383.

HANKS, S.K., QUINN, A.M., and HUNTER, T. (1988). The protein kinase family: Conserved features and deduced phylogeny of the catalytic domains. Science 241, 42-52.

HARPUR, A.G., ANDRES, A.-C., ZIEMIECKI, A., ASTON, R.R., and WILKS, A.F. (1992). JAK2, a third member of the JAK family of protein tyrosine kinases. Oncogene 7, 1347-1353.

HERBOMEL, P., BOURACHOT, B., and YANIV, M. (1984). Two distinct enhancers with different cell specificities coexit in the regulatory region of polyoma. Cell 39, 653-662.

HO, S.N., HUNT, H.D., HORTON, R.M., PULLEN, J.K., and PEASE, L.R. (1989). Site-directed mutagenesis by overlap extension using the polymerase chain reaction. Gene 77, 51-59.

HUANG, C.J., LEE, M.S., HUANG, F.L., and CHANG, G.D. (1995). A protease inhibitor of the serpin family is a major protein in carp perimeningeal fluid: II. cDNA cloning, sequence analysis, and Escherichia coli expression. J. Neurochem. 64, 1721-1727.

HUNTER, T., and COOPER, J.A. (1985). Protein-tyrosine kinases. Annu. Rev. Biochem. 54, 897-930.

IHLE, J.N., and KERR, I.M. (1995). Jaks and Stats in signaling by the cytokine receptor superfamily. Trends Genet. 11, 69-74.

IHLE, J.N., WITTHUHN, B.A., QUELLE, F.W., YAMAMOTO, K., THIERFELDER, W.E., KREIDER, B., and SILVENNOINEN, O. (1994). Signaling by the cytokine receptor superfamily: JAKs and STATs. Trends Biochem. Sci. 19, 222-227.

JUCKER, M., ROEBROEK, A.J., MAUTNER, J., KOCH, K., EICK, D., DIEHL, V., VAN DE VEN, W.J., and TESCH, H. (1992). Expression of truncated transcripts of the proto-oncogene c-fps/fes in human lymphoma and lymphoid leukemia cell lines. Oncogene 7 , 943-952.

KAWAGISHI, J., KUMABE, T., YOSHIMOTO, T., and YAMAMOTO, T. (1995). Structure, organization, and transcription units of the human a-platelet-derived growth factor receptor gene, PDGFRA. Genomics 30, 224-232.

LEE, W., MITCHELL, P., and TJIAN, R. (1987). Purified transcription factor AP-1 interacts with TPA-inducible enhancer elements. Cell 40, 741-752.

LICHTENBERG, U., QUINTRELL, N., and BISHOP, J.M. (1992) Human protein tyrosine kinase gene $H C K$ : Expression and structural analysis of the promoter region. Oncogene 7, 849-858.

MIYAZAKI, T., KAWAHARA, A., FUJII, H. NAKAGAWA, Y., MINAMI, Y., LIU, Z.-J., OISHI, I., SILVENNOINEN, O., WITTHUHN, B.A., IHLE, J.N., and TANIGUCHI, T. (1994). Functional activation of Jak 1 and Jak 3 by selective association with IL-2 receptor subunits. Science 266, 1045-1047.

MULlER, M., BRISCOE, J., LAXTON, C., GUSCHIN, D., ZIEMIECKI, A., SILVENNOINEN, O., HARPUR, A.G., BARBIERI, G., WITTHUHN, B.A., SCHINDLER, C., PELLEGRINI, S., WILKS, A.F., IHLE, J.N., STARK, G.R., and KERR, I.M. (1993). The protein tyrosine kinase JAK 1 complements defects in interferon$\alpha / \beta$ and $-\gamma$ signal transduction. Nature 366, 129-135. 
MULLIS, K.B., and FALOONA, F.A. (1987). Specific synthesis of DNA in vitro via a polymerase-catalyzed chain reaction. Methods Enzymol. 155, 335-350.

MURRE, C., SCHONLEBER MCCAW, P., and BALTIMORE, D. (1989). A new DNA binding and dimerization motif in immunoglobulin enhancer binding, daughterless, MyoD, and myc proteins. Cell 56, 777-783.

NICHOLSON, S.E., OATES, A.C., HARPUR, A.G., ZIEMIECKI, A., WILKS, A.F., and LAYTON, J.E. (1994). Tyrosine kinase JAK1 is associated with the granulocyte-colony-stimulating factor and both become tyrosine-phosphorylated after receptor activation. Proc. Natl. Acad. Sci. USA 91, 2985-2988.

NISHIZAWA, M., SEMBA, K., YOSHIDA, M.C., YAMAMOTO, T., SASAKI, M., and TOYOSHIMA, K. (1986). Structure, expression and chromosomal location of the human c-fgr gene. Mol. Cell Biol. 6, 511-517.

PATEL, M., LEEVERS, S.J., and BRICKELL, P.M. (1990). Structure of the complete human c-fgr protooncogene and identification of multiple transcriptional start sites. Oncogene 5, 201-206.

PAWSON, T., and SCHLESSINGER, J. (1993). SH2 and SH3 domains. Curr. Biol. 3, 434-442.

PEREZ-CASTRO, A.V., WILSON, J., and ALTHERR, M.R. (1995). Genomic organization of the mouse fibroblast growth factor receptor $3(F g f r 3)$ gene. Genomics 30, 157-162.

QUELLE, F.W., SATO, N., WITTHUHN, B.A., INHORN, R.C., EDER, M., MIYAJIMA, A., GRIFFIN, J.D., and IHLE, J.N. (1994). JAK2 associated with the $\beta c$ chain of the receptor for granulocytemacrophage colony-stimulating factor, and its activation requires the membrane-proximal region. Mol. Cell. Biol. 14, 4335-4341.

ROUER, E., HUYNH, T.V., LAVAREDA DE SOUZA, S., LANG, M.C., FISCHER, S., and BERNAROUS, R. (1989). Structure of the human lck gene: differences in genomic organization within src-related genes affect only N-terminal exons. Gene 84, 105-113.

RUI, H., KIRKEN, R.A., and FARRAR, W.L. (1994). Activation of receptor-associated tyrosine kinase JAK2 by prolactin. J. Biol. Chem. 269, 5364-5368.

RUSSELL, S.M., JOHNSTON, J.A., NOGUCHI, M., KAWAMURA, M., BACON, C.M., FRIEDMANN, M., BERG, M., MCVICAR, D.W., WITTHUHN, B.A., SILVENNOINEN, O., GOLDMAN, A.S., SCHMALSTIEG, F.C., IHLE, J.N., O'SHEA, J.J., and LEONARD, W.J. (1994). Interaction of IL-2R $\beta c$ and $\gamma$ chains with Jak1 and Jak3: implications for XSCID and XCID. Science 266, 1042-1045.

SAMBROOK, J., FRITSCH, E.F., and MANIATIS, T. (1989). Molecular Cloning: A Laboratory Manual. (Cold Spring Harbor Laboratory Press, Cold Spring Harbor, NY).

SANGER, F., NICKLEN, S., and COULSON, A.R. (1977). DNA sequencing with chain-terminating inhibitors. Proc. Natl. Acad. Sci. USA 74, 5463-5467.

SCHAGGER, H., and VON JAGOW, G. (1987). Tricine-sodium dodecyl sulfate-polyacrylamide gel electrophoresis for the separation of proteins in the range from 1 to $100 \mathrm{kDa}$. Anal. Biochem. 166, 368-379.

SCHAUFELE, F., WEST, B.L., and REUDELHUBER, T. (1990). Somatotroph- and lactotroph-specific interactions with the homeobox protein binding sites in the rat growth hormone gene promoter. Nucleic Acids Res. 18, 5235-5244.

SHINDLER, C., and DARNELL, J.E., JR. (1995). Transcriptional responses to polypeptide ligands: The JAK/STAT pathway. Annu. Rev. BIochem. 64, 621-651.

SHORT, J.M., FERNANDEZ, J.M., SORGE, J.A., and HUSE, W.D. (1988). Lamda ZAP: a bacteriophage lamda expression vector with in vivo excision properties. Nucleic Acids Res. 16, 7583-7600.

SHUAI, K., ZIEMIECKI, A., WILKS, A.F., HARPUR, A.G., SADOWSKI, H.B., GILMAN, M.Z., and DARNELL, J.E., JR. (1993).
Polypeptide signalling to the nucleus through tyrosine phosphorylation of Jak and STAT proteins. Nature 366, 580-583.

SIDERAS, P., MULLER, S., SHIELS, H., KHAN, W.N., NILSSON, L., PARKINSON, E., THOMAS, J.D., BRANDEN, L., LARSSON, I., PAUL, W.E., ROSEN, F.S., ALT, F.W., VETRIE, D., SMITH, C.I.E., and XANTHOPOULOS, K.G. (1994). Genomic organization of mouse and human Bruton's agammaglobulinemia tyrosine kinase (Btk) loci. J. Immunol. 153, 5607-5617.

SILVENNOINEN, O., WITTHUHN, B.A., QUELLE, F.W., CLEVELAND, J.L., YI, T., and IHLE, J.N. (1993). Structure of the murine $\mathrm{Jak} 2$ protein-tyrosine kinase and its role in interleukin 3 signal transduction. Proc. Natl. Acad. Sci. USA 90, 8429-8433.

STAHL, N., BOULTON, T.G., FARRUGGELLA, T., IP, N.Y., DAVIS, S., WITTHUHN, B.A., QUELLE, F.W., SILVENNOINEN, O., BARBIERI, G., PELLEGRINI, S., IHLE, J.N., and YANCOPOULOS, G.D. (1994). Association and activation of Jak-Tyk kinases by CTNFLIF-OSM-IL6 beta receptor components. Science 263, 92-95.

STAHL, N., FARRUGGELLA, T.J., BOULTON, T.G., ZHONG, Z., DARNELL JR., J.E., and YANCOPOULOS, G.D. (1995). Choice of STATs and other substrates specified by modular tyrosine-based motifs in cytokine receptors. Science 267, 1349-1353.

TAMAI, T., SHIRAHATA, S., NOGUCHI, T., SATO, N., KIMURA, S., and MURAKAMI, H. (1993). Cloning and expression of flatfish (Paralichthys olivaceus) interferon cDNA. Biochim. Biophy. Acta 1174, 182-186.

TANAKA, A., GIBBS, C.P., ARTHUR, R.R., ANDERSON, S.K., KUNG, H.-J., and FUJITA, D.J. (1987). DNA sequence encoding the amino- terminal region of the human c-src protein: implications of sequence divergence among src-type kinase oncogenes. Mol. Cell Biol. 7, 1978-1983.

UCHIUMI, F., SEMBA, K., YAMANASHI, Y., FUJISAWA, J., YOSHIDA, M., INOUE, K., TOYOSHIMA, K., and YAMAMOTO, T. (1992). Characterization of the promoter region of the src family gene lyn and its trans activation by human T-cell luekemia virus type I-encoded p40tax. Mol. Cell. Biol. 12, 3784-3795.

ULLRICH, A., and SCHLESSINGER, J. (1990). Signal transduction by receptors with tyrosine kinase activity. Cell 61, 203-212.

VEILLETTE, A., BOOKMAN, M.A., HORAK, E.M., and BOLEN, J.B. (1988). The CD4 and CD8 T cell surface antigens are associated with the internal membrane tyrosine-protein kinase $\mathrm{p} 56^{\text {lck }}$. Cell 55, 301-308.

VELAZQUEZ, L., FELLOUS, M., STARK, G.R., and PELLEGRINI, S. (1992). A protein tyrosine kinase in the interferon $\alpha / \beta$ signaling pathway. Cell 70, 313-322.

VILLALBA, M., WENTE, S.R., RUSSELL, D.S., AHN, J., REICHELDERFER, C.F., and ROSEN, O.M. (1989). Another version of the human insulin receptor kinase domain: expression, purification, and characterization. Proc. Natl. Acad. Sci. USA 86, 7848-7852.

WAIGMANN, H. (1993). Characterization of the human CSK locus. Oncogene 8, 1365-1369.

WATLING, D., GUSCHIN, D., MULLER, M., SILVENNOINEN, $O$. WITTHUHN, B.A., QUELLE, F.W., ROGERS, N.C., SCHINDLER, C., STARK, G.R., IHLE, J.N., and KERR, I.M. (1993). Complementation by the protein tyrosine kinase JAK2 of a mutant cell line defective in the interferon- $\gamma$ signal transduction pathway. Nature 366, 166-170.

WILKS, A.F. (1989). Two putative protein tyrosine kinases identified by application of the polymerase chain reaction. Proc. Natl. Acad. Sci. USA 86, 1603-1607.

WILKS, A.F., HARPUR, A.G., KURBAN, R.R., RALPH, S.J., ZURCHER, G., and ZIEMIECKI, A. (1991). Two novel proteintyrosine kinases, each with a second phosphotransferase-related catalytic domain, define a new class of protein kinase. Mol. Cell. Biol. 11, 2057-2065. 
WITTHUHN, B.A., QUELLE, F.W., SILVENNOINEN, O., YI, T., TANG, B., MIURA, O., and IHLE, J.N. (1993). JAK2 associated with the erythropoietin receptor and is tyrosine phosphorylated and activated following stimulation with erythropoietin. Cell 74, 227-236.

WITTHUHN, B.A., SILVENNOINEN, O., MIURA, O., LAI, K.S., CWIK, C., LIU, E.T., and IHLE, J.N. (1994). Involvement of the Jak-3 Janus kinase in signaling by interleukins 2 and 4 in lymphoid and myeloid cells. Nature 370, 153-157.

YANG, X., CHUNG, D., and CEPKO, C.L. (1993). Molecular cloning of the murine JAK1 protein tyrosine kinase and its expression in the mouse central nervous system. J. Neurosci. 13, 3006-3017.

YANISCH-PERRON, C., VIEIRA, J., and MESSING, J. (1985). Improved M13 phage cloning vectors and host strains: nucleotide sequences of the M13mp18 and pUC19 vectors. Gene 33, 103-119.
ZIEGLER, S.F., PLEIMAN, C.M., and PERLMUTTER, R.M. (1991). Structure and expression of the murine hck gene. Oncogene 6, 283-288. ZIEMIECKI, A., HARPUR, A.G., and WILKS, A.F. (1994). JAK protein tyrosine kinases: their role in cytokine signalling. Trends Cell Biol. 4, 207-212.

Address reprint requests to:

Dr. Chang-Jen Huang Institute of Biological Chemistry Academia Sinica P.O. Box 23-106

Taipei, Taiwan.

Received for publication December 12, 1996; accepted April $17,1996$. 